\title{
Reliable, robust and realistic: the three R's of next-generation land-surface modelling
}

\author{
I. C. Prentice ${ }^{1,2}$, X. Liang ${ }^{3}$, B. E. Medlyn ${ }^{2,4}$, and Y.-P. Wang ${ }^{5}$ \\ ${ }^{1}$ AXA Chair of Biosphere and Climate Impacts, Grand Challenges in Ecosystems and the Environment and Grantham \\ Institute - Climate Change and the Environment, Department of Life Sciences, Silwood Park Campus, Ascot, \\ Imperial College London, UK \\ ${ }^{2}$ Department of Biological Sciences, Macquarie University, North Ryde, New South Wales 2109, Australia \\ ${ }^{3}$ Department of Civil and Environmental Engineering, University of Pittsburgh, Pennsylvania, USA \\ ${ }^{4}$ Hawesbury Institute for the Environment, University of Western Sydney, Locked Bag 1797, Penrith, \\ New South Wales, Australia \\ ${ }^{5}$ CSIRO Ocean and Atmosphere Flagship, Private Bag 1, Aspendale, Victoria, Australia
}

Correspondence to: I. C. Prentice (c.prentice@ imperial.ac.uk)

Received: 28 July 2014 - Published in Atmos. Chem. Phys. Discuss.: 26 September 2014

Revised: 9 April 2015 - Accepted: 13 April 2015 - Published: 29 May 2015

\begin{abstract}
Land-surface models (LSMs) are increasingly called upon to represent not only the exchanges of energy, water and momentum across the land-atmosphere interface (their original purpose in climate models), but also how ecosystems and water resources respond to climate, atmospheric environment, land-use and land-use change, and how these responses in turn influence land-atmosphere fluxes of carbon dioxide $\left(\mathrm{CO}_{2}\right)$, trace gases and other species that affect the composition and chemistry of the atmosphere. However, the LSMs embedded in state-of-the-art climate models differ in how they represent fundamental aspects of the hydrological and carbon cycles, resulting in large inter-model differences and sometimes faulty predictions. These "thirdgeneration" LSMs respect the close coupling of the carbon and water cycles through plants, but otherwise tend to be under-constrained, and have not taken full advantage of robust hydrological parameterizations that were independently developed in offline models. Benchmarking, combining multiple sources of atmospheric, biospheric and hydrological data, should be a required component of LSM development, but this field has been relatively poorly supported and intermittently pursued. Moreover, benchmarking alone is not sufficient to ensure that models improve. Increasing complexity may increase realism but decrease reliability and robustness, by increasing the number of poorly known model parameters. In contrast, simplifying the representation of com-
\end{abstract}

plex processes by stochastic parameterization (the representation of unresolved processes by statistical distributions of values) has been shown to improve model reliability and realism in both atmospheric and land-surface modelling contexts. We provide examples for important processes in hydrology (the generation of runoff and flow routing in heterogeneous catchments) and biology (carbon uptake by speciesdiverse ecosystems). We propose that the way forward for next-generation complex LSMs will include: (a) representations of biological and hydrological processes based on the implementation of multiple internal constraints; (b) systematic application of benchmarking and data assimilation techniques to optimize parameter values and thereby test the structural adequacy of models; and (c) stochastic parameterization of unresolved variability, applied in both the hydrological and the biological domains.

\section{Introduction}

The land surface, together with the soil column underneath it, plays a key role in controlling not only the partitioning of available energy (into latent, sensible and ground heat fluxes) and water (into evapotranspiration, surface runoff, interflow, baseflow and soil moisture), but also the land-atmosphere exchange of carbon dioxide $\left(\mathrm{CO}_{2}\right)$ and the close coupling 
between photosynthesis and the cycling of energy and water vapour. Adequate representations of biological, physical and hydrological processes in a land-surface model (LSM) are therefore a prerequisite for improving the accuracy of both numerical weather forecasts and climate predictions. LSMs also provide a valuable tool to assess water resources, and the hydrological impacts of changes in climate and land use, over large river basins and continents, having the advantage of a globally consistent physical basis (Eagleson, 1986; Harrison et al., 1991). Moreover, LSMs are being required to perform new functions. In emerging Earth system models, they are called upon to model land-atmosphere exchanges of biogenic greenhouse gases other than $\mathrm{CO}_{2}$; other reactive trace gases with influences on atmospheric chemistry and composition; emissions of aerosols in biomass burning and dust deflation; and emissions of volatile organic compounds as aerosol precursors. This list could be continued, and is lengthening as knowledge increases about the diversity and complexity of Earth system interactions and feedbacks (Friedlingstein et al., 2013; Scholze et al., 2013; Ciais et al., 2014).

Many LSMs now include representations of the slower processes of vegetation dynamics, coupled to the fast exchanges of water, energy, momentum and $\mathrm{CO}_{2}$ that are at their core (Arora, 2002). Dynamic global vegetation models (DGVMs) have been reviewed elsewhere (e.g. Prentice et al., 2007; Tang and Bartlein, 2008; Prentice and Cowling, 2013). Some offline DGVMs (i.e. models not coupled to a climate model) have been used to address water resources questions (e.g. Rost et al., 2008; Murray et al., 2011, 2012a, b). Thus the boundaries between LSMs, DGVMs and global hydrological models are increasingly blurred. Here we focus on LSMs sensu stricto but our treatment applies equally to the representation of core land-surface processes in DGVMs. We first briefly review the evolution of land-surface modelling, then proceed to consider the present state of the art and how it could be improved upon.

The three R's of the title are all generally recognized as important characteristics of a numerical model, but models often do not possess all three. Possession of one feature does not by any means guarantee the rest. By reliable, we mean a model that gives approximately correct predictions under most circumstances. By robust, we mean a model whose results do not depend sensitively on the specification of quantities that are poorly known. By realistic, we mean a model that includes sufficient processes, represented in adequate detail, to allow simulation of the system's response to a change in all of the external variables of interest. We will argue that the dominant paradigm in land-surface modelling focusses too heavily on realism at the expense of the other two R's.

\section{Evolution of land-surface models}

Land-surface modelling consists of the development and application of computational models integrating biological, hydrological, and physical processes within the soil-plantatmosphere continuum. LSMs have two essential characteristics: (1) they consider processes related to the energy, water, and carbon cycles and their interactions, and (2) they operate over relatively large spatial domains with short temporal scales. Depending on their complexity, different LSMs may consider different processes and represent them differently.

Manabe (1969) was the first to include land-surface interactions explicitly in a climate model. Manabe's so-called bucket model includes vastly simplified hydrology (for example, no surface runoff is generated until the entire soil column reaches saturation), a simple energy balance equation, and no explicit vegetation characteristics. But Manabe's pioneer work ignited many significant developments in later LSMs.

In common with several earlier reviews including the influential article by Sellers et al. (1997), we consider the subsequent evolution of LSMs as a sequence of "generations", with Manabe's bucket model representing the first generation. But whereas Sellers et al. (1997) focused exclusively on LSMs as a component of climate models, our treatment also covers the extensive offline development of LSMs for hydrological applications that took place from the late 1980s onwards.

The pioneers of the second generation of LSMs were Deardorff (1978), Dickinson et al. (1986, 1993) (the BATS model) and Sellers et al. (1986, 1996) (the SiB model). These "generation 2A" LSMs focused on achieving a much more detailed representation of vegetation as the locus of many of the physical exchanges between land and the atmosphere, and a more realistic computation of the surface energy budget (Fig. 1). Later models followed along similar lines, including a variety of innovative components (e.g. Noilhan and Planton, 1989; Xue et al., 1991; Koster and Suarez, 1992; Ducoudré et al., 1993; Verseghy et al., 1993; Viterbo and Beljaars, 1995; Wetzel and Boone, 1995; Desborough and Pitman, 1998).

Parallel developments in offline models (Fig. 2) tackled problems caused by the unresolved (subgrid-scale) variability of precipitation and land-surface characteristics (topography, vegetation and soils). Because of the extreme nonlinearity of many key processes, disregarding this variability can lead to substantially incorrect computations of the aggregate surface water and energy budgets (e.g. Chen et al., 1997). Stochastic parameterizations, discussed in more depth later, were introduced as a means to deal with this problem of subgrid-scale variability. Attention was also paid to improving the representation of specific hydrological processes including infiltration, surface and subsurface runoff, and processes associated with snow. Representative LSMs in this "generation 2B" include the VIC (Liang et al., 1994, 1996a, b; Liang and Xie, 2001), TOPLATS (e.g. Famiglietti 


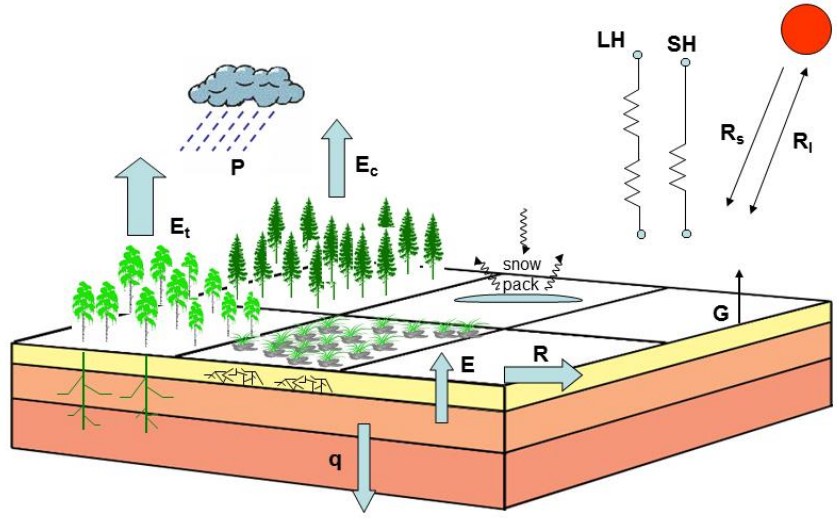

Figure 1. Schematic of "generation 2A" LSMs. The energy budget is represented by short-wave radiation $\left(R_{\mathrm{S}}\right)$, long-wave radiation $\left(R_{1}\right)$, latent heat flux $(\mathrm{LH})$, sensible heat flux $(\mathrm{SH})$ and ground heat flux $(G)$. The water budget is represented by $P$ (precipitation), $E$ (bare ground evaporation), $E_{\mathrm{t}}$ (transpiration), $E_{\mathrm{c}}$ (evaporation from canopy interception) and surface runoff $(R)$. The water budget is coupled with the energy budget, but hydrological processes are represented very simply; for example, subsurface runoff is represented only by vertical drainage $(q)$. Precipitation, vegetation type and soil properties are treated as constant within each grid cell.

and Wood, 1994; Peters-Lidard et al., 1997) and NOAH (e.g. Chen et al., 1996; Schaake et al., 1996) models, and the work of Ducharne et al. (1999) based on the TOPMODEL framework.

Crossley et al. (2000) and Gedney and Cox (2003) noted that inadequate representations of hydrological processes can significantly limit our ability to project future climate change and its impacts. Improvements in hydrological process representation (including runoff, groundwater exchanges, snow and frozen soil) continued in many second-generation LSMs (e.g. Koster et al., 2000; Liang and Xie, 2001; Milly and Shmakin, 2002; Cherkauer and Lettenmaier, 2003; Liang et al., 2003; Huang et al., 2008), providing more realistic representations of land-atmosphere water and energy exchanges. An additional focus was on achieving better representation of canopy hydrology, based on the schemes of Shuttleworth (1988), Liang et al. (1996b) and Wang and Wang (2007), for instance, to account for the effects of subgrid variability in precipitation on its partitioning to the different components of evapotranspiration and runoff.

The third generation of LSMs (Fig. 3) was developed with the principal motivation to solve a "new" problem, the representation of the carbon cycle in climate models. Representative work includes that of Bonan (1995), Sellers et al. (1996), Cox et al. (1998), and Dai et al. (2003). Our designation of these models as the third generation is consistent with Sellers et al. (1997) and Pitman (2003), who provided comprehensive discussions of them. The appearance of the thirdgeneration models in particular marked a transition from the representation of the surface conductance to water vapour -

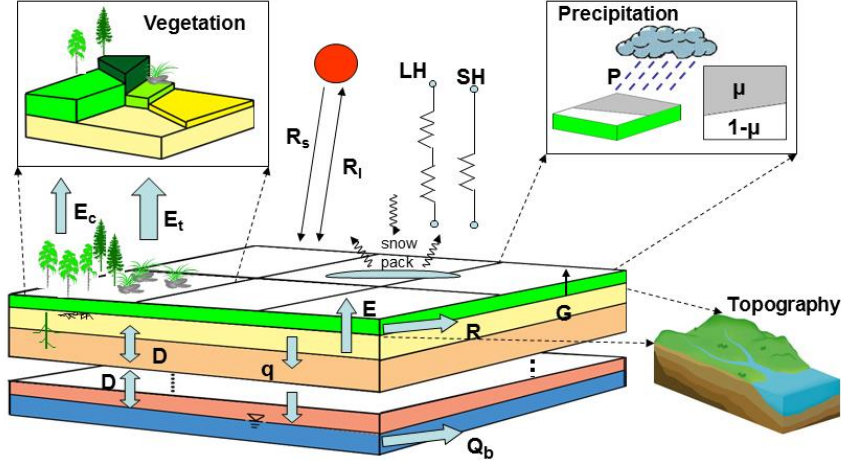

Figure 2. Schematic of "generation 2B" LSMs. See Fig. 1 for basic symbols. In addition, subgrid variabilities of precipitation, vegetation type, soil properties and topography are represented statistically ( $\mu$ represents the variable precipitation-covered area) and hydrological processes are represented more explicitly. Thus surface and subsurface runoff $\left(Q_{b}\right.$ and $q$ ) are distinguished, and diffusion $(D)$, lateral flow in the subsurface $\left(Q_{b}\right)$, and groundwater table dynamics are also modelled.

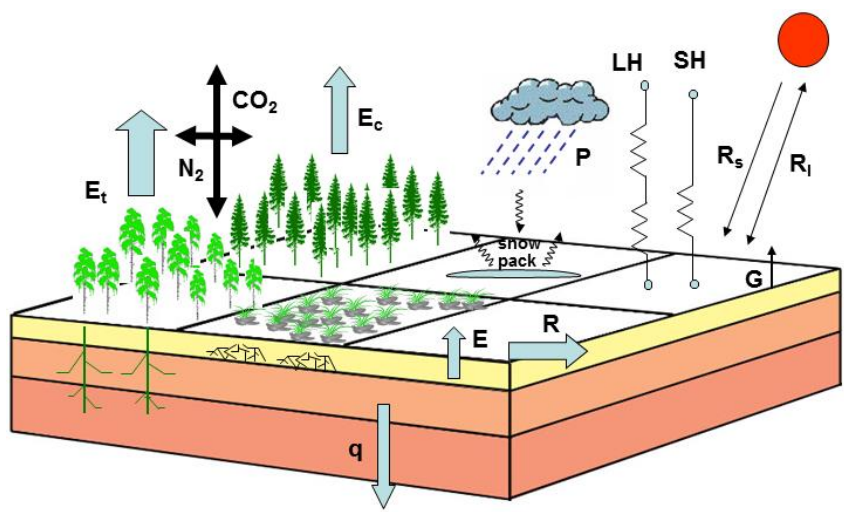

Figure 3. Schematic of "third-generation" LSMs, which are similar to generation 2A (Fig. 1) except that now the carbon budget is coupled to the calculation of the water and energy budgets through parameterizations of stomatal behaviour. However, these models do not incorporate the improved treatments of subgrid spatial variability and hydrological processes developed in generation 2B (Fig. 2).

a key quantity determining the evapotranspiration rate - by empirical relationships to multiple environmental predictors, to a new representation that explicitly recognized the close coupling between $\mathrm{CO}_{2}$ and water exchanges across the surface of leaves. This innovation allowed a simultaneous reduction in complexity and an improvement in realism. The closure schemes used to predict stomatal conductance at the leaf level have remained largely empirical, but Medlyn et al. (2011) showed how all of the commonly used expressions (including the Ball-Berry, Leuning and Jacobs formulae) can be interpreted as approximations of a single equation that represents biologically optimized stomatal behaviour. Prentice et al. (2014) further generalized the derivation of Medlyn et al.'s equation, showing how this can be predicted based 
on the relative carbon "costs" of maintaining the water flow pathway required for transpiration and the biochemical capacity for photosynthesis.

Representing land-atmosphere exchanges of water and carbon also required a representation of dynamic changes in green vegetation cover, especially the seasonal cycle. But how to represent vegetation phenology in a model is still a work in progress. Two principal approaches can be distinguished: plant-physiological (e.g. Lu et al., 2001) and rulebased (e.g. Foley et al., 1996; Levis and Bonan, 2004; Kim and Wang, 2005). This remains one of the least well modelled aspects of the land surface (Keenan et al., 2014). One promising avenue of development considers the biologically adaptive nature of phenology (Caldararu et al., 2014), leading to the idea of biologically optimized control of leaf flushing and senescence.

Many LSMs are now coupled to explicit representations of vegetation dynamics, represented by quantitative mixtures of plant functional types (PFTs) that are updated at intervals much longer than the time step of the LSMs. The landsurface component of many climate and Earth system models is therefore now a full DGVM, representing a cascade of processes with intrinsic time scales ranging from minutes to centuries, with asynchronous coupling to link faster and slower processes (Prentice et al., 2007). This development could, optimistically, be regarded as a major achievement in the integration of physical and biological aspects of the land surface (McGill et al., 2006). However, as discussed in the next section, the performance of such models has proved inconsistent. Reliability appears to have been lost in the scramble to develop multifunctional LSMs. Furthermore, the thirdgeneration models and DGVMs have generally not fully capitalized on advances in the representation of subgrid-scale heterogeneity and hydrological processes made in the second generation. The time is ripe for a synthesis of these elements.

\section{Model comparisons, evaluations, and the need for benchmarking}

The Programme for Intercomparison of Land-surface Parameterization Schemes (PILPS) was founded in the early 1990s (Henderson-Sellers et al., 1993, 1995) as an attempt to make sense of large differences that had been noted in the behaviour of contemporary LSMs, through community involvement in standardized model "experiments". The specific goal of PILPS was to improve understanding and implementation of first- and second-generation LSMs, as used to represent land-surface physical processes at regional to continental scales.

PILPS was one of six international efforts later subsumed under the umbrella of the Global Land/Atmosphere System Study (GLASS). GLASS aims to improve model representations of land-surface states and fluxes, to better understand interactions of the land surface with the overlying atmosphere, and to maximize the fraction of inherent predictability in land-atmosphere coupled processes (van den Hurk et al., 2011). PILPS has been through five phases: documenting the status of LSMs (Phase 0), performing offline tests of LSMs using synthetic atmospheric forcings (Phase 1a-c), using observed forcings and observations to evaluate the performance of LSMs offline (Phase 2a-e), coupling tests of LSMs within the Atmospheric Model Intercomparison Project (AMIP) (Phase 3), and evaluation of the performance of LSMs when coupled to their host climate models (Phase 4) (Henderson-Sellers et al., 1996). Results of "point" and small-area studies from PILPS 1a-c and 2a, $\mathrm{b}$ and $\mathrm{d}$ revealed large differences among models, and the fact that many diverged considerably from observations (e.g. Shao and Henderson-Sellers, 1995; Henderson-Sellers et al., 1996; Chen et al., 1997; Schlosser et al., 2000).

PILPS 2c and 2e were carried out for large river basins: $2 \mathrm{c}$ focusing on the mid-latitude Red-Arkansas River basin in the central USA, 2e on high-latitude Torne-Kalix basin in Sweden. The principal findings (Liang et al., 1998; Lohmann et al., 1998a; Wood et al., 1998; Bowling et al., 2003a, b; Nijssen et al., 2003) were as follows. (1) LSMs that applied subgrid-scale runoff parameterizations could simulate largescale river discharges better than others. (2) The modelled partitioning between surface and subsurface runoff varied even more than the modelled total runoff. In particular, the runoff parameterizations of LSMs under dry conditions were found to need improvement (Lohmann et al., 1998b; Bowling et al., 2003a). (3) The attenuation of solar short-wave radiation by vegetation needs to be considered in order to calculate the ground heat flux properly (Liang et al., 1998). (4) The partitioning of water and energy (i.e. the modelling of runoff and evapotranspiration) differed greatly among LSMs, even on an annual and monthly basis and even when the same forcing data, vegetation and soil information, and model parameters were used. (5) Mean values and spatial patterns of net radiation and surface temperature in warm conditions generally showed the best agreement among the LSMs, and with observations (Liang et al., 1998). (6) Models that conducted calibrations on some of their parameters performed consistently better than those that did not, regardless of the specific calibration method used. (7) Some model parameters in LSMs were found to be particularly critical for the partitioning of water and energy. For example, in the high-latitude study (PILPS 2e), it was shown using a simple "equivalent model" that variations in the partitioning of precipitation and energy at an annual scale could be attributed primarily to parameters related to snow albedo, effective aerodynamic resistance and evaporation efficiency (Bowling et al., 2003b).

For the mid-latitude study (PILPS 2c), Liang and Guo (2003) applied the fractional factorial method to ten LSMs in order to investigate the sensitivities of four quantities (annual evapotranspiration, total runoff, sensible heat flux, and soil moisture), and their combined effects, to five parameters that the models had in common: maximum soil 
moisture content (MSMC), effective available water content, the Clapp-Hornberger $B$ parameter, leaf area index, and minimum stomatal resistance. It was shown that MSMC and the Clapp-Hornberger $B$ were usually the most critical. This study also indicated that variations associated with soil properties (due to measurement uncertainties, and/or spatial heterogeneity) played a stronger role in the partitioning of water and energy budgets than those associated with vegetation properties. Sensitivities to different parameters were found to vary across hydroclimates, and generally the effects of different parameterizations were greater under arid than moist conditions (also shown by Lohmann et al., 1998a).

Despite the achievements of PILPS, and subsequent projects with more specific goals including GSWP (Global Soil Wetness Project: Dirmeyer et al., 1999, 2006), GLACE (Global Land Atmosphere Coupling Experiment: Koster et al., 2004, 2010) and LUCID (Land-Use and Climate, IDentification of robust impacts: Pitman et al., 2009), many of the most general questions originally posed are still unanswered. This situation was articulated in a review of GLASS by van der Hurk et al. (2011). For example, it is still not clear to what extent predictability can be achieved in a LSM; what parameterizations are more appropriate, under what conditions; and what is the best strategy to reduce prediction uncertainties. Moreover, many of the differences among LSMs, and discrepancies between LSMs and observations, have not been resolved and remain incompletely understood.

The coordinated international activities described above focused on the comparison and evaluation of LSMs sensu stricto. The international LAnd Model Benchmarking (iLAMB) project was inaugurated in 2009 with the explicit goal of a unified approach to the comparison and evaluation of land models including both carbon and water cycling aspects, and an unstated one, to rekindle apparently flagging enthusiasm for the evaluation and improvement of land models of all kinds. The project recognized from the outset its equal relevance to DGVMs, LSMs and numerical weather prediction. The project's stated goals are to (quoted from http://www.ilamb.org/, accessed 20 April 2014):

1. "to develop internationally accepted benchmarks for land model performance,

2. promote the use of these benchmarks by the international community for model intercomparison,

3. strengthen linkages between experimental, remote sensing, and climate modelling communities in the design of new model tests and new measurement programs, and

4. support the design and development of a new, open source, benchmarking software system for use by the international community."

These goals set out exactly what is required in order to make systematic testing against observations into a routine part of model development. However, the most recent iLAMB workshop took place in January 2011, and the stated goals seem to be some way from achievement. Some groups have published "first draft" sets of benchmark protocols and metrics (Randerson et al., 2009; Kelley et al., 2013) principally (not exclusively) focused on the carbon-cycle aspects. The Protocol for the Analysis of Land-Surface models (PALS) software (Abramowitz, 2005) allows rapid comparison of modelled and observed $\mathrm{CO}_{2}$ and latent heat fluxes at the publicly available eddy-covariance flux measurement stations in the FLUXNET archive. The ecosystem Modelling And Scaling infrasTructure (eMAST) project of the Australian Terrestrial Ecosystem Research Network (TERN) (http://www.tern.org.au/) is assembling diverse data sets and developing software to facilitate terrestrial ecosystem datamodel comparison and integration, with an initial focus on the Australian continent. This is by no means a comprehensive list of such initiatives. Nevertheless, our impression is that there is still limited momentum in the coordinated development of international benchmark systems, and that this is to the detriment of LSM improvement.

In summary, the development of LSMs in the climate modelling context has been characterized by intermittent and insufficient attention to model evaluation (Prentice, 2013). Probably as a direct consequence, those aspects of climate model predictions of the historical observational record that depend most strongly on the land-surface component are subject to remarkably large differences between models, which affect the quantification of both climate feedbacks (Ciais et al., 2014) and impacts with major consequences for human society (Schellnhuber, 2014). Two such areas of major disagreement among models were highlighted in the IPCC Fourth Assessment Report (Denman et al., 2007), and persisted without resolution into the Fifth:

(a) The hydrological cycle, specifically the degree to which precipitation over the continents depends on soil moisture and evapotranspiration from the land surface. The GLACE-1 experiment (Koster et al., 2002) showed that different GCMs behave very differently in this respect. Although the differences could be partly due to different schemes for generating precipitation in the atmosphere, the evidence points to differences among LSMs as a prime suspect.

(b) The carbon cycle, specifically the degree to which the growth rate of $\mathrm{CO}_{2}$ in future is likely to be reduced due to enhancement of NPP ("CO 2 fertilization": a negative feedback), and also the extent of compensating increase due to the acceleration of soil organic matter decay in a warming climate (a positive feedback). In the Coupled Carbon-Climate Model Intercomparison Project ( $\mathrm{C}^{4} \mathrm{MIP}$ ) (Friedlingstein et al., 2006) the participating models agreed that the sign of the feedback from climate change to atmospheric $\mathrm{CO}_{2}$ is positive, i.e. the effect of a warming climate is to release 
$\mathrm{CO}_{2}$ from the land surface. Some new models including $\mathrm{C}-\mathrm{N}$ cycle coupling have predicted the opposite sign, i.e. a negative feedback (Thornton et al., 2007; Sokolov et al., 2008), although this is not consistent with evidence from past changes in atmospheric $\mathrm{CO}_{2}$ concentration shown in ice-core records of the past millennium (Friedlingstein et al., 2010). The models reported in the IPCC Fifth Assessment Report (AR5) have produced carbon-climate feedbacks with consistently positive sign, but varying greatly in magnitude (Ciais et al., 2014). Most of the AR5 models underestimate the historical $\mathrm{CO}_{2}$ uptake by ocean and land (Hoffman et al., 2014). A model comparison against two Free Air Carbon dioxide Enrichment (FACE) experiments (Zaehle et al., 2014) found that the land $\mathrm{C}$ cycle component of one model in AR5 that includes a representation of $\mathrm{C}-\mathrm{N}$ cycle coupling (CLM4) systematically underestimated the observed response of NPP to $\mathrm{CO}_{2}$ enhancement.

The differences among different models' predictions of 21st century $\mathrm{CO}_{2}$ uptake have remained large through successive IPCC Assessments (Fig. 4). Alarmingly, the spread of modelled present values of gross primary production (GPP) and latent heat flux $(\lambda \mathrm{E})$, integrated across the global land surface - arguably the most fundamental of all carbon-cycle and hydrological quantities - is wide, with many modelled values falling well outside of accepted, observationally based ranges (Fig. 5). The problem here is not properly characterized as "uncertainty". It is rather that many models are certainly incorrect in their representation of the recent past.

It has become recognized across the community of land surface and vegetation modellers that (a) multiple observational constraints are possible, and (b) more systematic application of these constraints is needed to improve confidence in land-surface modelling. Recent reviews (Luo et al., 2012; Foley et al., 2013) and proof-of-concept studies (Randerson et al., 2009; Kelley et al., 2013; Piao et al., 2013) have promoted the concept of model benchmarking against a range of carbon-cycle and hydrological indicators. This is a welcome development. But benchmarking is not a panacea, and there are limits to the extent to which the routine application of observational data sets and data-model comparison metrics can constrain models. Some aspects also need close attention to developments in process understanding, e.g. experimental studies of $\mathrm{CO}_{2}$ effects on plants (Ainsworth and Long, 2005), or the effects of land-use changes on catchment hydrology (e.g. Siriwardena et al., 2006). Increased confidence in model performance can be achieved through the evaluation of specific assumptions embedded in models against experimental data (Medlyn et al., 2015).

Attention also needs to be paid to model structure, and especially to the way in which natural variability and heterogeneity in biological and physical quantities is represented. It is still common practice in LSMs and DGVMs for highly variable quantities to be represented by a single-valued pa-

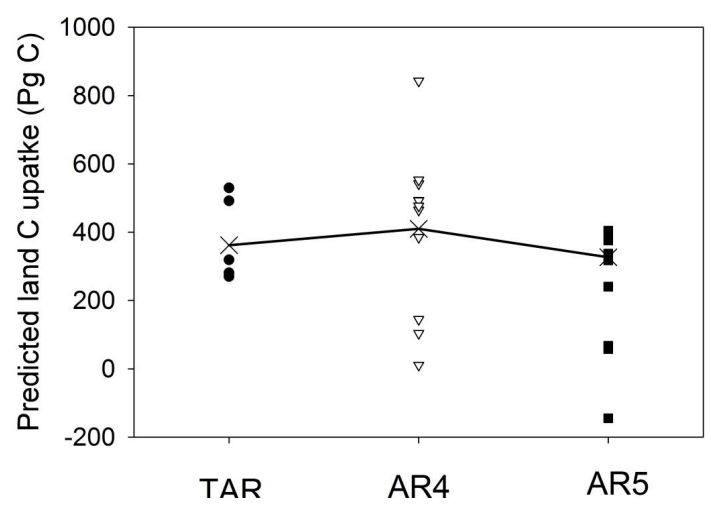

Figure 4. Simulated land carbon uptake to 2100 under a "high-end" global warming scenario, as projected by global models in the IPCC Third Assessment Report (TAR), Fourth Assessment Report (AR4) and Fifth Assessment Report (AR5). The cross represents the mean of the models included in each assessment.
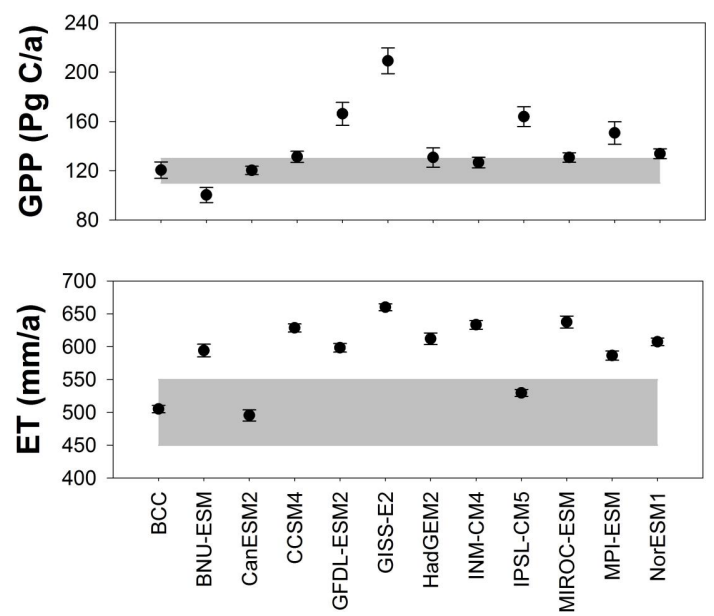

Figure 5. Mean annual gross primary production $\left(\mathrm{PgCa}^{-1}\right)$ and evapotranspiration $\left(\mathrm{mm} \mathrm{a}^{-1}\right)$ from the global land surface during 1901-2010, as simulated by 12 Earth system models in the IPCC Fifth Assessment Report. The grey lines represent upper and lower limits based on observations.

rameter. For example the hydrological properties of soils are usually assumed either globally constant, or assigned a constant value for each of a small number of soil texture classes; and in any case assigned a constant value across each model grid cell. Biological properties such as leaf photosynthetic capacity have been treated analogously. Many models assign constant biological parameter values within each of a small number of plant functional types (PFTs) even though up to $75 \%$ of the observed variation in some important plant traits occurs within PFTs (Kattge et al., 2011). Such devices have the potential to generate artefacts, which should be identifiable as a systematic failure to meet benchmarks. In Sect. 5 we discuss examples of an alternative general approach that appears to yield more robust results. 


\section{Complexity vs. robustness}

As more processes continue to be identified and included in LSMs, the almost universal tendency is for LSMs to become more and more complex. A worrying side-effect is the progressive introduction of more model parameters with (commonly) substantially uncertain values. Moreover, complexity can conceal lack of rigour, because it becomes progressively easier to fit observations as more parameters are introduced. Thus, increasing complexity can mask a lack of understanding, resulting in a situation whereby models are tuned to perform well at standard tests but produce widely divergent results when projected beyond the domain of calibration. This seems to be precisely the situation currently observed with coupled carbon-cycle-climate models, as reported in AR5 (Ahlström et al., 2012; Anav et al., 2013; Arora et al., 2013; Jones et al., 2013; Todd-Brown et al., 2013; Ciais et al., 2014). Although it seems reasonable to expect that a model including a larger subset of processes that are known to be important should be more realistic than a simpler model, increases in reliability and robustness by no means automatically follow.

Comparative studies have shown that indeed, complexity in land surface models has not generally improved their reliability (e.g. Desborough and Pitman, 1998). Furthermore, there is no point in achieving sophistication in one set of processes while retaining simple empiricism in another. Complexity needs to be balanced. This is not a precisely defined principle, but it is an important practical one (Smith et al., 2013). We suggest that there is often a trade-off between complexity and robustness, and that robustness is more important than (often spurious) precision. Whereas the representation of a complex system cannot be achieved in a simple model, it seems of paramount importance that complexity is dealt with in a carefully controlled manner that minimizes the scope for over-fitting and thus for the spurious impression of predictive skill.

\section{Stochastic parameterization}

Stochastic (or statistical) parameterization has gained considerable traction in the atmospheric modelling community, where it has been shown to yield improved robustness and to reduce model artefacts in the numerical representation of weather processes (e.g. Palmer, 2012; Arnold et al., 2013). Stochastic parameterizations represent one or more model parameters as a statistical distribution of values. Atmospheric modelling differs from land-surface modelling in that the equations describing weather processes are inherently chaotic, requiring ensembles of simulations to achieve probabilistic forecasts; implementing a stochastic parameterization in this context can be done by allowing ensemble members to differ in the assignment of parameter values. The equations describing carbon and water cycle processes at and below the land surface are in principle deterministic, in a given environment (Xia et al., 2013). However, the land surface - in contrast with the atmosphere - is heterogeneous at spatial scales down to metres and below, and this heterogeneity cannot be explicitly resolved for the purposes of large-scale modelling. Some form of parameterization is required. Similarly, the ecosystem consists of species with a range of properties, whose aggregate behaviour is not accurately represented by the behaviour of a single species; but a complete enumeration of species and their functional properties would be entirely impractical. As in the atmosphere, the processes represented can be highly non-linear, so that the mean behaviour of the system is not satisfactorily captured by its behaviour at the mean values of the system's parameters. This is a general property of non-linear systems. Stochastic parameterizations get around this difficulty, and they can often be implemented in a computationally efficient way, avoiding the need for multiple model runs by including calculations on probability density functions within a single realization of the model.

\subsection{Hydrological examples}

Because runoff is the residual of two relatively large quantities (precipitation vs. evapotranspiration and changes in soil water storage), and because there are no direct observations of evapotranspiration over large areas, streamflow data continue to have a great potential to be used to evaluate LSMs' simulation of land-atmosphere latent heat and water vapour exchange. (This situation is evolving as improved methods for deriving evapotranspiration from remotely sensed measurements are developed: see Mueller et al., 2013.) Many LSMs fail to generate realistic temporal distributions of streamflow, limiting the potential for such data to be used to test and constrain LSMs. The fundamental problem is that the pointwise generation of runoff is a threshold process (compounded by other highly non-linear properties, including the relationship between hydraulic conductivity and soil water potential) and soil and topographic properties are highly variable. Representing this system by a single "typical" soil profile results in too sharp a transition between high and low flows.

An effective solution to this problem was embedded in the VIC (which stands for "Variable Infiltration Capacity") LSM (Liang et al., 1994, 1996a) in which the subgrid-scale spatial variabilities of both soil moisture capacity and potential infiltration rate are represented by statistical distributions (Liang and Xie, 2001). The impact of subgrid-scale variability of precipitation is also considered (Liang et al., 1996a). These aspects of variability have significant consequences for the grid-cell total values of the components of the water budget, which are better modelled as a result. VIC has been widely used for land-surface and hydrological impact studies. The soil-moisture capacity curve (a statistical distribution) used for the saturation-excess surface-runoff parameterization in 
VIC has been implemented in the ISBA (Habets et al., 1999) and SEWAB (Mengelkamp et al., 1999) LSMs. VIC has been used as a tool to provide retrospective global surface water flux fields (Nijssen et al., 2001). The runoff parameterization of VIC has also been implemented in the Community Land Model (CLM4VIC: Li et al., 2011).

The development of VIC recognized that heterogeneity of land-surface properties is ubiquitous on all spatial scales, down to metres and below. Therefore increasing spatial resolution, tiling, grid nesting and similar devices cannot solve the problem of heterogeneity. Instead, VIC represents subgrid-scale heterogeneity statistically, taking into account the spatial autocorrelation properties as well as variability per se. VIC cannot provide location-specific information on fluxes within each grid cell, but this does not matter, because the objective is only to provide robust information integrated across the grid cell.

Liang and Guo (2003) showed that LSMs such as ISBA and VIC, which explicitly represent the subgrid-scale spatial variability of soil, vegetation, and/or atmospheric forcings, can be less sensitive to the choice of parameter values and thereby produce more robust results, and several other studies have supported this conclusion (e.g. Liang et al., 1996b, 2004; Koren et al., 1999; Li et al., 2011). VIC is insensitive to the assumption of different precipitation distributions within the precipitation-covered area (e.g. Liang et al., 1996b) compared to other LSMs that treat soil properties as invariant (Pitman et al., 1990), and is robust with respect to changes in grid resolution and selection of parameter values (Liang et al., 2004).

A parallel approach has been applied to the routing of streamflow by Wen et al. (2012). This routing scheme, an extension of the one proposed by Guo et al. (2004), applies a statistical distribution for the overland flow path. It is different in several respects from other commonly used routing schemes. Runoff from a grid cell is allowed to exit in multiple directions and a tortuosity coefficient is used to account for geomorphic properties such as channel slope and length. The flow network differentiates explicitly between overland and river flows. The scheme as implemented by Wen et al. (2012) was found to dramatically reduce the dependence of the routing model on the time step, and to produce good results for hourly flows (needed, for example, for flood prediction) where the previous, deterministic parameterization had failed altogether.

DGVMs, even when used for water resources applications, have not generally included parameterizations of landsurface physical variability. However, the inclusion of such a parameterization can greatly improve the hydrological outputs of DGVMs (e.g. Li and Ishidaira, 2011). Exactly why stochastic parameterizations work so well in the context of real landscapes is a research question greatly in need of further study. However, it is worth noting that the statistical properties of landscapes are by no means arbitrary, but are predictable in principle based on the nature of erosion pro- cesses (e.g. Turcotte, 2007; Saeki and Okamura, 2010), presumably leading to commonalities that can be exploited for modelling.

\subsection{A biological example}

Gross primary production (GPP, the space-time integral of carbon uptake by photosynthesis) is the basis of all plant growth. Its global total value is reasonably well constrained by observations (Wang et al., 2014). There is a close coupling between GPP and transpiration, because stomatal opening and closure regulates both $\mathrm{CO}_{2}$ uptake into and water loss out of leaves. Adequate estimation of GPP in the third-generation LSMs is therefore important for modelling the hydrological cycle as well as the carbon cycle. Some of the parameters of photosynthesis (the in vivo enzyme kinetic constants and their temperature responses) can be regarded as constant and well known for global modelling purposes, but others - notably the maximum rate of carboxylation, $V_{\mathrm{cmax}}$, and at least one parameter characterizing the relationship between stomatal conductance and vapour pressure deficit - vary greatly, both within and among species. The usual approach to provide values of these variables in LSMs has been to draw on literature sources to estimate values of each parameter, with the parameters thereby treated as constant (within PFTs) and independent of one another.

There has been little systematic investigation of the consequences of these assumptions. However, just as the representation of hydrological responses can be improved by accounting for the variation and autocorrelation of physical properties within the landscape, it seems likely that the representation of $\mathrm{CO}_{2}$ uptake could be improved by accounting for the variation and covariation of ecophysiological properties within the community of species that carry out photosynthesis.

A vast amount of empirical work during the past decade has gone into the compilation of relevant trait measurements from many plant species (see Wright et al., 2004; Kattge et al., 2011), so the single-value approach can no longer be justified by the paucity of available data (as was the case during the early years of LSM development). In addition to the large variation within PFTs (Kattge et al., 2011), a key finding of this research has been that the parameters, far from being independent, show correlations, so that the variation among species can be collapsed into a few dimensions. One of these dimensions is the so-called leaf economics spectrum, relating photosynthetic rates, leaf longevity and specific leaf area (Wright et al., 2004). Although there has been criticism of the presentation of the leaf economics spectrum, centring on the existence of necessary correlations among various combinations of measurements, its existence and biological significance are not in any doubt (e.g. Lloyd et al., 2013).

In a typical LSM representation, GPP depends on canopy leaf area index and $V_{\text {cmax }}$. Canopy leaf area index is modelled as a function of the fraction of net primary production 
allocated to leaves and of the leaf lifespan ( $\tau$ in years), and $V_{\text {cmax }}$ is modelled as a function of leaf nitrogen per unit leaf area - i.e. the product of leaf nitrogen concentration $(n$ in $\left.\mathrm{g} \mathrm{N} \mathrm{g}^{-1}\right)$ and leaf mass per area $\left(m\right.$ in $\left.\mathrm{g} \mathrm{m}^{-2}\right)$. Field observations from over 50000 plant species show that leaf lifespan and leaf mass per area are positively correlated, while both are negatively correlated with leaf nitrogen concentration (Wright et al., 2004). Using the CABLE LSM (Kowalczyk et al., 2006; Wang et al., 2010; Wang, 2011), Wang et al. (2012) calculated the global mean and standard deviation of modelled GPP using two groups of 500 randomly sampled sets of the three leaf traits $n, \tau$ and $m$ with their observed means and standard deviations. One group also applied the observed covariances of the traits while the other group assumed zero covariance. Simulated global GPP was found to vary from 115 to $170 \mathrm{Gt} \mathrm{Ca}^{-1}$ when the three model parameters were varied independently. Including covariances did not change the mean GPP, but reduced its standard deviation by $28 \%$, indicating that the observed trait correlations help to constrain the modelled value of global total GPP.

This analysis by Wang et al. (2012) represents a first step towards the realistic inclusion of plant trait variability and correlation patterns in LSMs. The adaptive DGVM approach (Scheiter and Higgins, 2009) represents a somewhat different implementation of stochastic parameterization of plant traits at the continental scale. The general idea that the functional diversity of plants should be represented by continuous trait variation, rather than by a small number of PFTs with fixed characteristics, has been repeatedly mooted (e.g. Kleidon, 2007; van Bodegom et al., 2012). Key to this approach is the idea that functional convergence (the achievement of similar, optimized large-scale fluxes by diverse communities of plants differing in phylogeny) is a consequence of biodiversity, with environmental selection and competition ensuring that niches are filled.

This idea also has the potential to simplify the modelling of GPP and eventually NPP, which is a key quantity for the terrestrial carbon cycle. For example, Wang et al. (2014) have shown that a model explicitly derived from optimality considerations - the least-cost hypothesis of Wright et al. (2003) and Prentice et al. (2014), and the co-limitation or coordination hypothesis (e.g. Maire et al., 2012) - can predict global patterns of forest GPP without the need for PFT-specific parameters. The same has not yet been done for NPP and biomass growth. But the least-cost hypothesis also makes explicit predictions about respiration costs; together with recent findings of general relationships between carbon use efficiency and soil nutrient status (Vicca et al., 2012; Fernández-Martínez, 2014), these predictions are likely to provide the basis for an equally general model of NPP.

\section{Towards next-generation models}

Figure 6 presents a view of what next-generation LSMs might look like. Key developments needed to make this level of complexity tractable are the implementation of multiple constraints; the use of data assimilation; and the application of stochastic parameterization as discussed above.

\subsection{Bounding complexity: the use of multiple constraints}

There are encouraging signs that ecologists and ecophysiologists, atmospheric scientists and hydrologists are beginning to work together to improve understanding of largescale ecosystem and landscape processes, and to identify and quantify the processes that need to be included in LSMs. For example, recognizing the role of deep roots in the function of the soil-plant-atmosphere continuum, researchers are now begin to investigate "new" processes including hydraulic redistribution (e.g. Lee et al., 2005; Amenu and Kumar, 2008; Li et al., 2011; Wang, 2011; Quijano et al., 2012; Luo et al., 2013; Prentice and Cowling, 2013), plant water storage (e.g. Luo et al., 2013), surface water and groundwater interactions (e.g. Winter, 2001; Gutowski et al., 2002; York et al., 2002; Liang et al., 2003; Maxwell and Miller, 2005; Yeh and Eltahir, 2005; Liang et al., 2003; Fan et al., 2007; Niu et al., 2007), and the interactions among these processes and with other existing processes in current LSMs (e.g. Luo et al., 2013). Further new developments include consideration of the relevance of agriculture, wetlands and lakes for the aggregate behaviour of the land surface (e.g. Rosnay et al., 2003; Ringeval et al., 2012; Webler et al., 2012; Drewniak et al., 2013).

With these aspects adding ever-increasing complexity, however, a new modelling strategy is required to ensure that the uncertainties do not spiral out of control as more and more uncertain parameters are introduced. The key lies in ensuring that physical and biological constraints are identified, and explicitly embedded in models. The application of observational constraints (benchmarking against multiple types of observations) routinely during model development is necessary, but not sufficient.

The key principle applied in the recent development of the VIC+ model (Luo et al., 2013) is to enforce multiple constraints on each process, as far as possible, to reduce the number of free (or highly uncertain) parameters in the model. The prototype for this approach was the realization that stomatal conductance to water vapour - which, when combined with leaf area index, is the largest land-surface control on the latent heat flux in vegetated landscapes - must conform (on a fast time scale of seconds) to the same equations (apart from a factor 1.6, relating the molecular diffusivities of water vapour and $\mathrm{CO}_{2}$ ) that describe how stomatal conductance to $\mathrm{CO}_{2}$ responds to environmental signals. This equality continues to hold even if stomatal conductance is reduced, and/or 


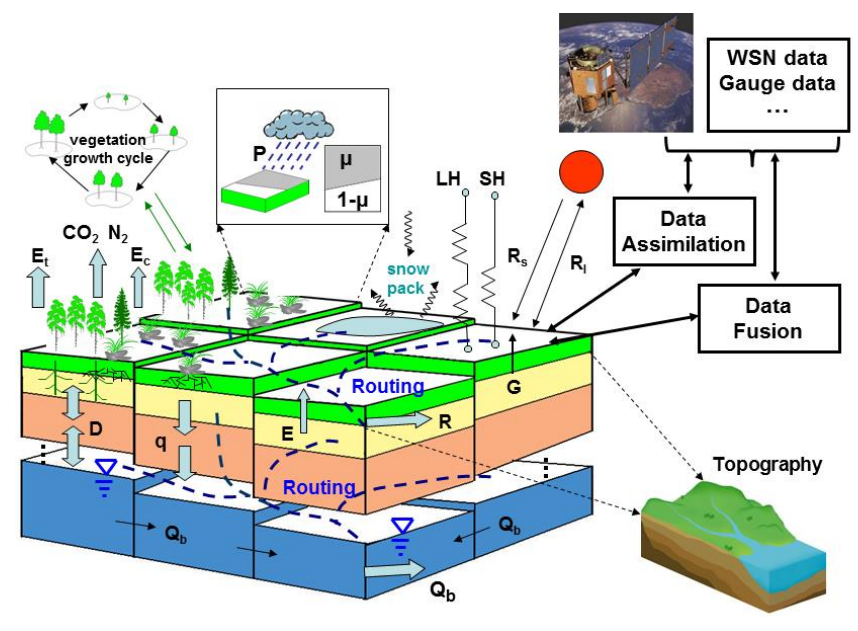

Figure 6. Hypothetical schematic of "next-generation" LSMs that will combine the desirable features of previous models, with the addition of surface and subsurface hydrological routing schemes and representations of vegetation dynamics. Model-data fusion and data assimilation will allow effective use of observations from different platforms. Experience suggests that it will be a major challenge to achieve such a complex, realistic representation of land-surface biology and hydrology without loss of reliability and robustness. The application of multiple physical and biological constraints, and the judicious use of stochastic parameterization for subgrid-scale processes, are advocated here as important tools for next-generation model development.

photosynthetic capacity inhibited, in response to soil drying (Tuzet et al., 2003; Zhou et al., 2013). Moreover, the rate of photosynthesis implied by the $\mathrm{CO}_{2}$ concentration difference across the stomata must be equal to the rate of photosynthesis implied by the incident photosynthetic photon flux density and key photosynthetic parameters $\left(V_{\mathrm{cmax}}\right.$ and $\left.J_{\max }\right)$. These insights were essential for the inclusion of coupled carbon and water exchanges in the third-generation LSMs (e.g. Collatz et al., 1991). But these are not the only relevant constraints. Allowing for small, but non-zero, water storage, the rate of evaporation at the leaf surface must be equal to the rate of water flow through the xylem; which in turn, following the Ohm's law analogy for water flows, must be equal to the product of plant hydraulic conductance and the water potential difference between the soil and the leaves. This constraint allows transpiration to be controlled by both the soil water potential of the root zone and the atmospheric conditions simultaneously, mediated by measurable plant characteristics (Tuzet et al., 2003). Figure 7 summarizes how the stomatal and hydraulic constraints are combined in VIC + to determine the transpiration rate.

VIC + also represents the influence of soil water potential (via its effect on transpiration, and thus leaf water potential) on stomatal conductance, according to the model of Tuzet et al. (2003) which in turn built on pioneering work by Cowan (1965). The calculation of $\mathrm{CO}_{2}$ assimilation in the

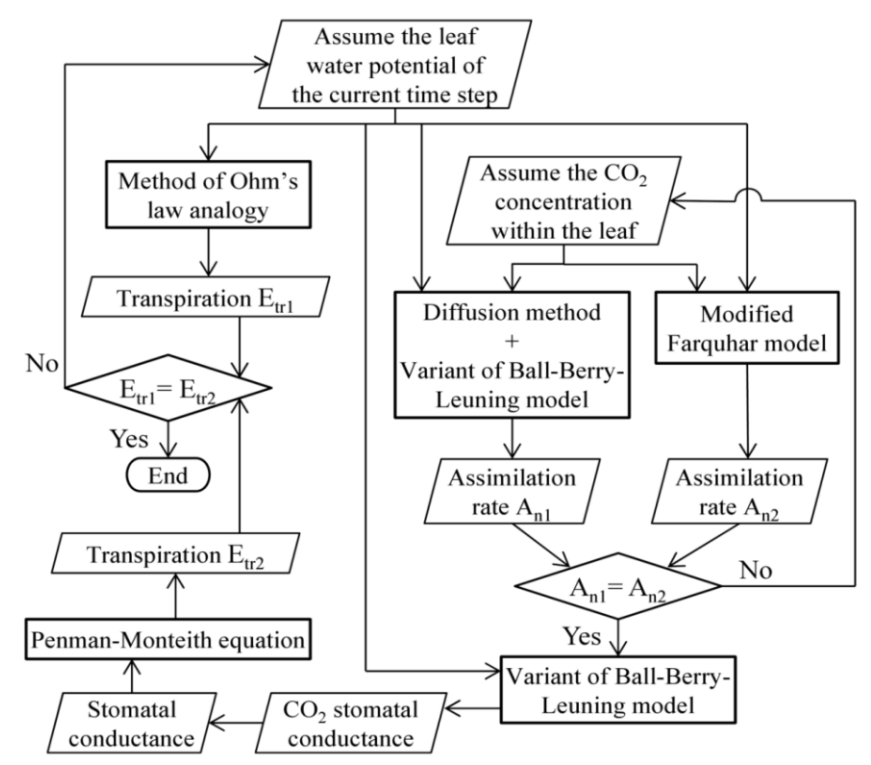

Figure 7. The computational representation of soil-plantatmosphere water and carbon fluxes in the VIC+ model. Consistency between carbon and water exchanges across the leaf surface, and between water transport from the soil, through plant transport tissues and into the boundary layer, are enforced by means of an iterative algorithm. Plant hydraulic properties (via the Ohm's law analogy) and stomatal responses thus simultaneously constrain both transpiration and assimilation. Rectangles indicate calculation processes; parallelograms represent variables. From Luo et al. (2013).

model is constrained as a consequence of the interplay of the stomatal and biochemical limitations simultaneously, taking into account the effect of soil moisture signalling, by way of computing the $\mathrm{CO}_{2}$ concentration within the leaf. If transpiration is appropriately represented by $E_{\mathrm{tr} 1}$ and $E_{\mathrm{tr} 2}$ (Fig. 7) then these two quantities must converge, as must the two rates $A_{\mathrm{n} 1}$ and $A_{\mathrm{n} 2}$ (also shown in Fig. 7) representing $\mathrm{CO}_{2}$ uptake.

The constraints discussed above pertain to physically necessary relationships between fluxes, arising from the architecture of leaves and plants. Potentially, many additional constraints may arise due to natural selection in biological systems, which acts to eliminate "ineffective" combinations of traits, even if they are not directly physically linked. The leaf economics spectrum provides one such set of constraints. The least-cost hypothesis introduced by Wright et al. (2003) and elaborated by Prentice et al. (2014) provides another, potentially powerful constraint, as it leads to an independent specification of the leaf-internal $\mathrm{CO}_{2}$ concentration as calculated in Fig. 7. The co-limitation (or coordination) hypothesis further leads to a prediction of both photosynthetic rate (given leaf temperature and internal $\mathrm{CO}_{2}$ concentration) and $V_{\text {cmax }}$ as a function of light availability (Dewar, 1996; Haxeltine and Prentice, 1996; Maire et al., 2012). The resistance to diffusion of $\mathrm{CO}_{2}$ in the mesophyll, between the intercellular spaces and the chloroplasts where photosynthesis is carried 
out, is often ignored but can be substantial, and has implications for the strength of $\mathrm{CO}_{2}$ fertilization (Sun et al., 2014). Again, there is an over-riding physical constraint, i.e. the flux of $\mathrm{CO}_{2}$ to the chloroplasts must match the net flux of $\mathrm{CO}_{2}$ into the leaves. $V_{\text {cmax }}$ no longer needs to be a PFT-specific parameter but can be predicted dynamically from environmental variations. Moreover the strong relationship between leaf nitrogen and $V_{\text {cmax }}$ provides a natural way to predict plant nitrogen demand, a key quantity in determining how plants allocate carbon to different functions. With consideration of biologically optimized constraints, we are optimistic that the number of unknown or poorly constrained parameters describing the controls of $\mathrm{CO}_{2}$ and water exchange by plants can be greatly reduced.

\subsection{Optimizing model performance: the potential of data assimilation}

Obtaining best estimates of parameters, given a set or multiple sets of observations, is one of the goals of data assimilation (e.g. Moradkhani et al., 2005a; Qin et al., 2009; Montzka et al., 2011; Vrugt et al., 2013). Data assimilation has evolved from Newtonian "nudging" to more comprehensive approaches including various flavours of traditional, extended, ensemble Kalman filtering, variational data assimilation using the adjoint method, and the particle filtering method (e.g. Houser et al., 1998; Walker and Houser, 2001; Reichle et al., 2002a, b; Margulis et al., 2002; McLaughlin, 2002; Crow and Wood, 2003; Montaldo and Albertson, 2003; Moradkhani et al., 2005a, b; Pan and Wood, 2006; Qin et al., 2009; Montzka et al., 2011; Vrugt et al., 2013). Parada and Liang (2004) developed a new spatial data assimilation framework, an extension of the Multiscale Kalman Smoother-based (MKS-based) framework (Chou et al., 1994; Fieguth et al., 1995; Luettgen and Willsky, 1995; Kumar, 1999). This framework is innovative in the way it accounts for error propagation, dissimilar spatial resolutions, and the spatial structure within which the distribution of the data is considered. Concepts from this framework have been adopted in several other data assimilation studies (e.g. Parada and Liang, 2008; Pan et al., 2009; Lannoy et al., 2010).

Techniques for data assimilation are thus an active research area. To an even greater extent than for model evaluation and benchmarking, however, the routine use of data assimilation is far from being common practice. It has been stated a number of times that data assimilation should be a standard part of model development. More work is needed to develop generic schemes that would allow data assimilation to be applied to any model, and to set up data sets and protocols for doing so.

Data assimilation, when used to optimize parameter values in a model, is valuable above all because it can potentially reveal whether or not a particular model structure is capable of generating the observed patterns. In normal practice, if a model fails a benchmark test, this does not necessarily indi- cate that the model is incorrectly specified; it could simply mean that the parameter values in the model are incorrect. If the model fails after assimilation of the relevant data set, however, this may be a strong indication that some structural aspect of the model needs improvement.

Data assimilation confronts a number of practical difficulties. Here we identify three issues that require further research for their satisfactory resolution.

1. High computational demand. Investigators have to choose between gradient-based methods and "bruteforce" ensemble simulation (Wang et al., 2009). Ensemble simulations are computationally extremely intensive and can easily become infeasible for global LSMs with several hundred parameters. Gradient-based methods use adjoint codes or finite-difference methods to compute the gradients that are required for optimization (Rayner et al., 2005). The gradient-based approach is many times more efficient than ensembles whenever a large number of parameters are to be optimized. However, adjoint code needs to be generated afresh whenever the model code is modified (Kaminski et al., 2013).

2. Maintaining mass and energy conservation in state assimilation. Compared to offline ecosystem models, one of the advantages of global LSMs is that they enforce the conservation of water, energy and carbon. However many state assimilation techniques do not automatically enforce conservation laws, and need to be modified accordingly. It has yet to be fully explored how such modification affects the parameter estimation process.

3. Quantifying uncertainties in multiple data sets for parameter estimation. Because state-of-the-art LSMs typically include processes with time constants ranging from hours to decades or beyond, multiple data sets with different characteristic temporal and spatial scales are needed to constrain all the model parameters. However the uncertainties of multiple data sets and how those uncertainties vary in space and time are poorly quantified in many cases - introducing an element of subjectivity into the analysis. This problem has been discussed by Raupach et al. (2005) and Wang et al. (2009). A general solution has yet to be found.

\section{Concluding remarks}

Substantial progress has been made in the development of LSMs since Manabe's pioneering work. The models will continue to evolve. They are already complex. They will become inevitably more complex as they come to represent (a) a more complete description of the set of key processes that determines the exchanges of materials and energy between the atmosphere and the underlying surface and subsurface, for example including surface and groundwater interactions, 
sediment transport, and biogeochemical interactions of the carbon, nitrogen and phosphorus cycles; (b) subgrid-scale spatial variability, reflecting the natural diversity of ecosystems and landscapes; and (c) processes requiring high temporal resolution: notably flooding, a key issue in a changing climate.

Process understanding continues to evolve, both in biology and in hydrology. At any one time, different models may reasonably differ in the explicit assumptions they make about key processes. This is unavoidable. We suggest that it is also desirable. Global models should incorporate explicit hypotheses about processes, and they are the tool that should allow these hypotheses at the process level to be tested against large-scale observations. Realization of this vision, however, will require teamwork: people with different disciplinary knowledge will need to work together with increased intensity. This is a prerequisite for LSMs to come into their own, as tools for discovery and improved quantitative understanding of the fundamental laws that control energy, water and carbon cycling between the atmosphere and land.

Observational data sets originating in different disciplines, including remote sensing, atmospheric chemistry, ecophysiology and hydrology, will need to be brought to bear routinely to benchmark models and thereby establish their reliability. Robustness will be achieved through the discovery of general regularities that obviate the need to specify large numbers of poorly known or ill-conditioned parameters, such as (non-existent) universal $V_{\text {cmax }}$ values for PFTs, and evaluated over time as a community enterprise facilitated by the open publication and sharing of code. Realism will be assessed not as an over-riding requirement to include every known process, but rather by models' ability to give consistent answers to scientific questions, such as the influence of different aspects of climate, environment and land use on global NPP.

The widening field of applications of models to project the consequences of a changing atmospheric and human environments calls for LSMs to be simultaneously reliable, robust and realistic (the three R's of the title) so that they can be used confidently, in new interdisciplinary contexts, to project consequences and potential policy implications of environmental change for agriculture, biodiversity, public health and human security. A new level of reliability is unlikely to be achieved through "business-as-usual" model development. More robust ways to model key processes are within reach, but will require both further scientific development and new code to be written. Several proposals now exist in the literature for possible community-wide benchmark standards, but progress on this front will require community adoption of such standards. A technical facility will be required to help make comprehensive LSM benchmarking and data assimilation a routine process. It will be challenging, but with determination and collaboration, it can be done.
Acknowledgements. This review originated in invited presentations by I. C. Prentice and X. Liang at the inaugural workshop of the Centre for Australian Weather and Climate (a joint activity of CSIRO and the Bureau of Meteorology) in Melbourne in 2007. The ideas were further developed at a workshop on the Hydrological Cycle held at Dartington Hall in 2008 and supported by the Quantifying and Understanding the Earth System (QUEST) programme of the UK Natural Environment Research Council, and at the iLAMB workshop held at the University of California, Irvine in 2011. I. C. Prentice acknowledges funding from the Australian Terrestrial Ecosystem Research Network (TERN) to the ecosystem Modelling And Scaling infrasTructure (eMAST) facility, and from the Australian Research Council (ARC) Discovery project (with Ian Wright) "Next-generation vegetation model based on plant functional types". X. Liang acknowledges funding from US Department of Energy grant DEFG0208ER64586 and US National Oceanographic and Atmospheric Administration grant NA09OAR4310168. B. E. Medlyn acknowledges funding from the ARC Discovery project (with I. C. Prentice) "Turning water into carbon: a synthesis of plant water-use efficiency from leaf to globe". Y.-P. Wang acknowledges Long Hui for providing the data for Figs. 4 and 5. I. C. Prentice and X. Liang jointly drafted the text, with contributions from B. E. Medlyn and Y.-P. Wang. X. Liang created the schematic diagrams. This paper is a contribution to the AXA Chair Programme on Biosphere and Climate Impacts, and the Imperial College initiative on Grand Challenges in Ecosystems and the Environment.

Edited by: M. Heimann

\section{References}

Abramowitz, G.: Towards a benchmark for land surface models, Geophys. Res. Lett., 32, L22702, doi:10.1029/2005GL024419, 2005.

Ahlström, A., Schurgers, G., Arneth, A., and Smith, B.: Robustness and uncertainty in terrestrial ecosystem carbon response to CMIP5 climate change projections, Environ. Res. Lett., 7, 044008, doi:10.1088/1748-9326/7/4/044008, 2012.

Ainsworth, E. A. and Long, S. P.: What have we learned from 15 years of free-air $\mathrm{CO}_{2}$ enrichment (FACE)? A meta-analytic review of the responses of photosynthesis, canopy properties and plant production to rising $\mathrm{CO}_{2}$, New Phytol., 165, 351-372, 2005.

Amenu, G. G. and Kumar, P.: A model for hydraulic redistribution incorporating coupled soil-root moisture transport, Hydrol. Earth Syst. Sci., 12, 55-74, doi:10.5194/hess-12-55-2008, 2008.

Anav, A., Friedlingstein, P., Kidston, M., Bopp, L., Ciais, P., Cox, P., Jones, C., Jung, M., Myneni, R., and Zhu, Z.: Evaluating the land and ocean components of the global carbon cycle in the CMIP5 Earth system mode, J. Climate, 26, 6801-6843, 2013.

Arnold, H. M., Moroz, I. M., and Palmer, T. N.: Stochastic parameterisations and model uncertainty in the Lorenz '96 system, Philos. T. R. Soc. A, 371, 201110479, doi:10.1098/rsta.2011.0479, 2013.

Arora, V.: Modelling vegetation as a dynamic component in soil-vegetation-atmosphere transfer schemes and hydrological 
models, Rev. Geophys., 40, 1006, doi:10.1029/2001RG000103, 2002.

Arora, V. K., Boer, G. J., Friedlingstein, P., Eby, M., Jones, C. D., Christian, J. R., Bonan, G., Bopp, L., Brovkin, V., Cadule, P., Hajima, T., Ilyina, T., Lindsay, K., Tjiputra, J. F., and Tongwen, W.: Carbon-concentration and carbon-climate feedbacks in CMIP5 Earth system models, J. Climate, 26, 5289-5314, 2013.

Bonan, G. B.: land-atmosphere $\mathrm{CO}_{2}$ exchange simulated by a land surface process model coupled to an atmospheric general circulation model, J. Geophys. Res., 100, 2817-2831, 1995.

Bowling, L. C., Lettenmaier, D. P., Nijssen, B., Graham, L. P., Clark, D. B., El Maayar, M., Essery, R., Goers, S., Gusev, Y., Habets, F.,van den Hurk, B., Jin, J., Kahan, D., Lohmann, D., Ma, X., Mahanama, S., Mocko, D., Nasonova, O., Niu, G., Samuelsson, P., Shmakin, A. B., Takata, K., Verseghy, D., Viterbo, P., Xia, Y., Xue, Y., and Yang, Z. L.: Simulation of high-latitude hydrological processes in the Torne-Kalix basin: PILPS Phase 2(e): 1. Experiment description and summary intercomparisons, Global Planet. Change, 38, 1-30, 2003a.

Bowling, L. C., Nijssen, B., Lettenmaier, D. P., Polcher, J., Koster, R. D., and Lohmann, D.: Simulation of high-latitude hydrological processes in the Torne-Kalix basin: PILPS Phase 2(e): 3. Sensitivity analysis, Global Planet. Change, 38, 55-71, $2003 \mathrm{~b}$.

Caldararu, S., Purves, D. W., and Palmer, P. I.: Phenology as a strategy for carbon optimality: a global model, Biogeosciences, 11, 763-778, doi:10.5194/bg-11-763-2014, 2014.

Chen, F., Mitchell, K., Schaake, J., Xue, J. K., Pan, H. L., Koren, V., Duan, Q. Y., Ek, M., and Betts, A.: Modelling of land surface evaporation by four schemes and comparison with FIFE observations, J. Geophys. Res., 101, 7251-7268, 1996.

Chen, T., Henderson-Sellers, A., Milly, P., Pitman, A., Beljaars, A., Abramopoulos, F., Boone, A., Chang, S., Chen, F., Dai, Y., Desborough, C., Dickinson, R., Dumenil, L., Ek, M., Garratt, J., Gedney, N., Gusev, Y., Kim, J., Koster, R., Kowalczyk, E., Laval, K., Lean, J., Lettenmaier, D., Liang, X., Mahfouf, J., Mengelkamp, H. -T., Mitchell, K., Nasonova, O., Noilhan, J., Polcher, J., Robock, A., Rosenzweig, C., Schaake, J., Schlosser, C., Schulz, J.P., Shao, Y., Shmakin, A., Verseghy, D., Wetzel, P., Wood, E., Xue, Y., Yang, Z. L., and Zeng, Q.: Cabauw experimental results from the Project for Intercomparison of Land-surface Parameterization Schemes - PILPS, J. Climate, 10, 1194-1215, 1997.

Cherkauer, K. A. and Lettenmaier D. P.: Simulation of spatial variability in snow and frozen soil, J. Geophys. Res., 108, 8858, doi:10.1029/2003JD003575, 2003.

Chou, K. C., Willsky, A. S., and Benveniste, A.: Multiscale recursive estimation, data fusion, and regularization, IEEE T. Automat. Contr., 39, 479-492, 1994.

Ciais, P., Sabine, C., Bala, G., Bopp, L., Brovkin, V., Canadell, J., Chhabra, A., DeFries, R., Galloway, J., Heimann, M., Jones, C., Le Quéré, C., Myneni, R. B., Piao, S., and Thornton, P.: Carbon and other biogeochemical cycles, in: Climate Change 2013: The Physical Science Basis, edited by: Stocker, T. F., Qin, D., Plattner, G. -K., Tignore, M., Allen, S. K., Boschung, J., Nauels, A., Xia, Y., Bex, V. and Midgley, P. M., Cambridge University Press, Cambridge, 2014.

Collatz, G. J., Ball, J. T.,Grivet, C., and Berry, J. A.: Physiological and environmental regulation of stomatal conductance, photosynthesis and transpiration: A model that includes a laminar boundary layer, Agr. For. Meteorol., 54, 107-136, 1991.
Cowan, I. R.: Transport of water in the soil-plant-atmosphere system, J. Appl. Ecol., 2, 221-239, 1965.

Cox, P. M., Huntingford, C., and Harding, R. J.: A canopy conductance and photosynthesis model for use in a GCM land surface scheme, J. Hydrol., 213, 79-94, 1998.

Crossley, J. F., Polcher, J., Cox, P. M., Gedney, N., and Planton, S.: Uncertainties linked to land-surface processes in climate change simulations, Clim. Dyn., 16, 949-961, 2000.

Crow, W. T. and Wood, E. F.: The assimilation of remotely sensed soil brightness temperature imagery into a land surface model using ensemble Kalman filtering: A case study based on ESTAR measurements during SGP97, Adv. Water. Resour., 26, 137-149, 2003.

Dai, Y. J., Zeng, X. B., Dickinson, R. E., Baker, I., Bonan, G. B., Bosilovich, M. G., Denning, A. S., Dirmeyer, P. A., Houser, P. R., Niu, G. Y., Oleson, K. W., Schlosser, C. A., and Yang, Z. L.: The Common Land Model, B. Am. Meteorol. Soc., 84, 1013-1023, 2003.

Deardorff, J. W.: Efficient prediction of ground surface temperature and moisture with inclusion of a layer of vegetation, J. Geophys. Res., 83, 1889-1903, 1978.

Desborough, C. E. and Pitman, A. J.: The BASE land surface model, Global Planet. Change, 19, 3-18, 1998.

Denman, K. L., Brasseur, G., Chidthaisong, A., Ciais, P., Cox, P. M., Dickinson, R. E., Hauglustaine, D., Heinze, C., Holland, E., Jacob, D., Lohmann, U., Ramachandran, S., da Silva Dias, P. L., Wofsy, S. C., and Zhang, X.: Coupling between changes in the climate system and biogeochemistry, in: Climate Change 2007: The Physical Science Basis, edited by: Solomon, S., Qin, D., Manning, M., Chen, Z., Marquis, M., Averyt, K. B., Tignor, M., and Miller, H. L., Cambridge University Press, Cambridge, 2007.

Dewar, R. C.: The correlation between plant growth and intercepted radiation: an interpretation in tems of optimal plant nitrogen content, Ann. Bot., 78, 125-136, 1996.

Dickinson, R. E., Henderson-Sellers, A., Kennedy, P. J., and Wilson, M. F.: Biosphere-Atmosphere Transfer Scheme (BATS) for the NCAR Community Climate Model, NCAR Tech. Note, TN$275+$ STR, 1986.

Dickinson, R. E., Henderson-Sellers, A., Kennedy, P. J., and Wilson, M. F.: Biosphere-Atmosphere Transfer Scheme (BATS) version 1e as coupled to Community Climate Model, NCAR Tech. Note, TN-387 + STR, 1993.

Dirmeyer, P. A., Dolman, A., and Sato, N.: The pilot phase of the Global Soil Wetness Project, B. Am. Meteorol. Soc., 80, 851878, 1999.

Dirmeyer, P. A., Gao, X., Zhao, M., Guo, Z., Oki, T., and Hanasaki, N.: GSWP-2: Multimodel analysis and implications for our perception of the land surface, B. Am. Meteorol. Soc., 87, 13811397, 2006.

Drewniak, B., Song, J., Prell, J., Kotamarthi, V. R., and Jacob, R.: Modeling agriculture in the Community Land Model, Geosci. Model Dev., 6, 495-515, doi:10.5194/gmd-6-495-2013, 2013.

Ducharne, A., Koster, R. D., Suarez, M. J., and Kumar, P.: A catchment-based land surface model for GCMs and the framework for its evaluation, Phys. Chem. Earth B, 24, 769-773, 1999.

Ducoudré, N. I., Laval, K., and Perrier, A.: SECHIBA: a new set of parameterizations of the hydrologic exchanges at the landatmosphere interface within the LMD atmospheric general circulation model, J. Climate, 6, 248-273, 1993. 
Eagelson, P. S.: The emergence of global-scale hydrology, Water Resour. Res., 22, 6S-14S, 1986.

Famiglietti, J. S. and Wood, E. F.: Multiscale modeling of spatiallyvariable water and energy-balance processes, Water Resour. Res., 30, 3061-3078, 1994.

Fan, Y., Miguez-Macho, G., Weaver, C. P., Walko, R., and Robock, A.: Incorporating water table dynamics in climate modelling: 1. Water table observations and equilibrium water table simulations, J. Geophys.. Res., 112, D10125, doi:10.1029/2006JD008111, 2007.

Fernández-Martínez, M., Vicca, S., Janssens, I. A., Sardans, J., Luyssaert, S., Campiolo, M., Chapin III, F. S., Ciais, P., Malhi, Y., Obersteiner, M., Paple, D., Piao, S. L., Reichstein, M., Roda, F. and Peñuelas, J.: Nutrient availability as the key regulator of global forest carbon balance, Nature Clim. Change, 4, 471-476, 2014.

Fieguth, P. W., Karl, W. C., Willsky, A. S., and Wunsch, C.: Multi-resolution optimal interpolation and statistical analysis of TOPEX/POSEIDON satellite altimetry, IEEE T. Geosci. Remote, 33, 280-292, 1995.

Foley, J. A., Prentice, I. C., Ramankutty, N., Levis, S., Pollard, D., Sitch, S., and Haxeltine, A.: An integrated biosphere model of land surface processes, terrestrial carbon balance, and vegetation dynamics, Glob. Biogeochem. Cy., 10, 603-628, 1996.

Foley, A. M., Dalmonech, D., Friend, A. D., Aires, F., Archibald, A. T., Bartlein, P., Bopp, L., Chappellaz, J., Cox, P., Edwards, N. R., Feulner, G., Friedlingstein, P., Harrison, S. P., Hopcroft, P. O., Jones, C. D., Kolassa, J., Levine, J. G., Prentice, I. C., Pyle, J., Vázquez Riveiros, N., Wolff, E. W., and Zaehle, S.: Evaluation of biospheric components in Earth system models using modern and palaeo-observations: the state-of-the-art, Biogeosciences, 10, 8305-8328, doi:10.5194/bg-10-8305-2013, 2013.

Friedlingstein, P., Cox, P., Betts, R., Bopp, L., Von Bloh, W., Broukin, V., Cadule, P., Doney, S., Eby, M., Fung, I., Bala, G., John, J., Jones, C., Joos, F., Kato, T., Kawamiya, M., Knorr, W., Lindsay, K., Matthews, H. D., Raddatz, T., Raynor, P., Reick, C., Roeckner, E., Schnitzler, K. G., Schnur, R., Strassman, K., Weaver, A. J., Yoshikawa, C., and Zeng, N.: Climate-carbon feedback analysis: results from the $\mathrm{C}^{4} \mathrm{MIP}$ model intercomparison, J. Climate, 19, 3337-3353, 2006.

Friedlingstein, P., Houghton, R. A., Marland, G., Hackler, J., Boden, T. A., Conway, T. J., Canadell, J. G., Raypach, M. R., Ciais, P., and Le Quéré, C.: Update on $\mathrm{CO}_{2}$ emissions, Nature Geosci., 3, 811-812, 2010.

Friedlingstein, P., Gallego-Sala, A. V., Blyth, E. M., Hewer, F. E., Seneviratne, S. O., Spessa, A., Suntharalingam, P., and Scholze, M.: The Earth system feedbacks that matter for contemporary climate, in: Understanding the Earth System: Global change science for applications, edited by: Cornell, S. E., Prentice, I. C., House, J. I., and Downy C. J., Cambridge University Press, Cambridge, 102-128, 2013.

Gedney, N. and Cox, P. M.: The sensitivity of global climate model simulations to the representation of soil moisture heterogeneity, J. Hydrometeorol., 4, 1265-1275, 2003.

Guo, J., Liang, X., and Leung, L. R.: A new multi-scale flow network generation scheme for land surface models, Geophys. Res. Lett., 31, L23502, doi:10.1029/2004GL021381, 2004.

Gutowski, W. J., Vorosmarty, C. J., Person, M., Otles, Z., Fekete, B., and York, J. A.: Coupled land-atmosphere simulation pro- gram (CLASP): calibration and validation, J. Geophys. Res., 107, 4283, doi:10.1029/2001JD000392, 2002.

Habets, F., Noilhan, J., Golaz, C., Goutorbe, J. P., Lacarrère, P., Leblois, E., Ledoux, E., Martin, E., Ottlé, C., and Vidal-Madjar, D.: The ISBA surface scheme in a macroscale hydrological model applied to the Hapex-Mobilhy area Part 1: Model and database, J. Hydrol., 217, 75-96, 1999.

Harrison, S. P., Choudhury, B. J., Cogley, G., Cramer, W., Hutchinson, M. F., Prentice, I. C., and Running, S.: A rationale, structure and research strategy for a global hydrological model, IIASA Working Papers, WP-91-27, 1-21, 1991.

Haxeltine, A. and Prentice, I. C.: BIOME3: An equilibrium terrestrial biosphere model based on ecophysiological constraints, resource availability, and competition among plant function types, Glob. Biogeochem. Cy., 10, 693-709, 1996.

Henderson-Sellers, A., Yang, Z. L., and Dickinson, R. E.: The project for intercomparison of land-surface parameterization schemes, B. Am. Meteorol. Soc., 74, 1335-1349, 1993.

Henderson-Sellers, A., Pitman, A. J., Love, P. K., Irannejad, P., and Chen, T. H.: The project for intercomparison of land surface parameterization schemes (PILPS): phases 2 and 3, B. Am. Meteorol. Soc., 76, 489-503, 1995.

Henderson-Sellers, A., McGuffie, K., and Pitman, A. J.: The project for intercomparison of land-surface parameterization schemes (PILPS): 1992 to 1995, Clim. Dynam., 12, 849-859, 1996.

Hoffman, F. M., Randerson, J. T., Arora, V. K., Bao, Q., Cadule, P., Ji, D., Jones, C. D., Kawamiya, M., Khatiwala, S., Lindsay, K., Obata, A., Shevliakova, E., Six, K. D., Tjiputra, J. F., Volodin, E. M., and $\mathrm{Wu}, \mathrm{T}$.: Causes and implications of persistent atmospheric carbon dioxide biases in Earth System Models, J. Geophys. Res., 119, 141-162, 2014.

Houser, P. R., Shuttleworth, W. J., Famiglietti, J. S., Gupta, H. V., Syed, K. H., and Goodrich, D. C.: Integration of soil moisture remote sensing and hydrologic modeling using data assimilation, Water Resour. Res., 34, 3405-3420, 1998.

Huang, M., Liang, X., and Leung, L. R.: A generalized subsurface flow parameterization considering subgrid spatial variability of recharge and topography, J. Hydrometeorol., 9, 1151-1171, 2008.

Jones, A. D., Collins, W. D., Edmonds, J., Torn, M. S., Janetos, A., Calvin, K. V., Thomson, P., Hurtt, G. C., and Wise, M.: Greenhouse gas policy influences climate via direct effects of land-use change, J. Climate, 26, 3657-3670, 2013.

Kaminski, T., Knorr, W., Schurmann, G., Scholze, M., Rayner, P. J., Zaehle, S., Blessing, S., Dorigo, W., Gayler, V., Giering, R., Gobron, N., Grant, J. P., Heimann, M., Hooker-Stroud, A., Houweling, S., Kato, T., Kattge, J., Kelley, D., Kemp, S., Koffi E. N., Kostler, C., Mathieu, P.-P., Pinty, B., Reick, C. H., Rodenbeck, C., Schnur, R., Scipal, K., Sebald, C., Stacke, T., Terwisschag Van Scheltinga, A., Vossbeck, M., Widmann, H., and Ziehn, T.: The BETHY/JSBACH carbon cycle data assimilation system: experiences and challenges, J. Geophys. Res., 118, 1414-1426, 2013.

Kattge, J., Díaz, S., Lavorel, S., Prentice, I. C., Leadley, P., Bönisch, G., Garnier, E., Westoby, M., Reich, P. B., Wright, I. J., Cornelissen, J. H. C., Violle, C., Harrison, S. P., van Bodegom, P. M., Reichstein, M., Soudzilovskaia, N. A., Ackerly, D. D., Anand, M., Atkin, O., Bahn, M., Baker, T. R., Baldocchi, D., Bekker, R., Blanco, C., Blonder, B., Bond, W., Bradstock, R., Bunker, 
D. E., Casanoves, F., Cavender-Bares, J., Chambers, J., Chapin, F. S., Chave, J., Coomes, D., Cluesener-Godt, M., Cornwell, W. K., Craine, J. M., Dobrin, B. H., Durka, W., Duarte, L., Elser, J., Enquist, B. J., Esser, G., Estiarte, M., Fagan, W. F., Fang, J., Fernández, F., Fidelis, A., Finegan, B., Flores, O., Frank, D., Freschet, G. T., Fyllas, N., Gallagher, R., Green, W., Gutierrez, A. G., Hickler, T., Higgins, S., Hodgson, J. G., Jalili, A., Jansen, S., Joly, C., Kerkhoff, A. J., Kirkup, D., Kitajima, K., Kleyer, M., Klotz, S., Knops, J. M. H., Kramer, K., Kühn, I., Kurokawa, H., Lange, O., Laughlin, D., Lee, T. D., Leishman, M., Lens, F., Lenz, T., Lewis, S., Lloyd, J., Llusià, J., Louault, F., Ma, S., Mahecha, M. D., Manning, P., Massad, T., Medlyn, B., Messier, J., Moles, A., Montserrat-Martí, G., Müller, S., Nadrowski, K., Naeem, S., Niinemets, Ü., Nöllert, S., Nüske, A., Ogaya, R., Oleksyn, J., Ordoñez, J., Onipchenko, V. G., Onoda, Y., Overbeck, G., Ozinga, W., Patiño, S., Paula, S., Pausas, J. G., Peñuelas, J., Phillips, O., Pillar, V., Poorter, H., Poorter, L., Poschlod, P., Proulx, R., Rammig, A., Reinsch, S., Reu, B., Sack, L., Salgado, B., Sardans, J., Soussana, J. -F., Shiodera, S., Shipley, B., Sosinski, E., Swaine, E., Swenson, N., Thompson, K., Thornton, P., Waldram, M., Weiher, E., White, M., Wright, S. J., Zaehle, S., Zanne A. E., and Wirth, C.: TRY - a global data base of plant traits, Glob. Change Biol., 17, 2905-2935, 2011.

Keenan, T. F., Gray, J., Friedl, M. A., Toomey, M., Bohrer, G., Hollinger, D. Y., Munger, J. W., O'Keefe, J., Schmid, H. P., Wing, I. S., Yang, B., and Richardson, A. D.: Net carbon uptake has increased through warming-induced changes in temperate forest phenology, Nature Clim. Change, 4, 598-604, doi:10.1038/nclimate2253, 2014.

Kelley, D. I., Prentice, I. C., Harrison, S. P., Wang, H., Simard, M., Fisher, J. B., and Willis, K. O.: A comprehensive benchmarking system for evaluating global vegetation models, Biogeosciences, 10, 3313-3340, doi:10.5194/bg-10-3313-2013, 2013.

Kim, Y. and Wang, G.: Modeling seasonal vegetation variation and its validation against Moderate Resolution Imaging Spectroradiometer (MODIS) observations over North America, J. Geophys. Res., 110, D04106, doi:10.1029/2004JD005436, 2005.

Kleidon, A.: Optimized stomatal conductance and the climate sensitivity to carbon dioxide, Geophys. Res. Lett., 34, L14709, doi:10.1029/2007GL030342, 2007.

Koren, V. I., Finnerty, B. D., Schaake, J. C., Smith, M. B., Seo, D. J., and Duan, Q. Y.: Scale dependencies of hydrologic models to spatial variability of precipitation, J. Hydrol., 217, 285-302, 1999.

Koster, R. D. and Suarez, M. J.: Modelling the land surface boundary in climate models as a composite of independent vegetation stands, J. Geophys. Res., 97, 2697-2715, 1992.

Koster, R. D., Suarez, M. J., Ducharne, A., Stieglitz, M., and Kumar, P.: A catchment-based approach to modelling land surface processes in a general circulation model: 1 . Model structure, J. Geophys. Res., 105, 24809-24822, 2000.

Koster, R. D., Dirmeyer, P. A., Hahmann, A. N., Ljpelaar, R., Tyahla, L., Cox, P., and Suarez, M. J.: Comparing the degree of land-atmosphere interaction in four atmospheric general circulation models, J. Hydometerol., 3, 363-375, 2002.

Koster, R. D., Dirmeyer, P. A., Guo, Z., Bonan, G., Chan, E., Cox, P., Gordon, C. T., Kande, S., Kowalczyk, E., Lawrence, D., Lui, P., Lu, C. -H., Malysheu, S., McAvaney, B., Mitchell, K., Mocko, D., Oki, T., Oleson, K., Pitman, A., Sud, Y. C., Taylor, C. M.,
Verseghy, D., Vasic, R., Xue, Y., and Yamada, T.: Regions of strong coupling between soil moisture and precipitation, Science, 305, 1138-1140, 2004.

Koster, R. D., Mahanama, S. P. P., Yamada, T. J., Balsamo, G., Berg, A. A., Boisserie, M., Dirmeyer, P. A., Doblas-Reyes, F. J., Drewitt, G., Gordon, C. T., Guo, Z., Jeong, J.-H., Lawrence, D. M., Lee, W. -S., Li, Z., Luo, L., Malyshev, S., Merryfield, W. J., Seneviratne, I., Stanelle, T., Van Den Hurk B. J. J. M., Vitart, F., and Wood, E. F.: Contribution of land surface initialization to subseasonal forecast skill: First results from a multi-model experiment, Geophys. Res. Lett., 37, L02402, doi:10.1029/2009GL041677, 2010.

Kowalczyk, E., Wang, Y. P., Law, R., Pak, B., and Abramowitz, G.: Land cover coupling to the climate system; implementing an interactive carbon cycle in ACCESS, CSIRO Marine and Atmospheric Research, Research Paper 013, 2006.

Kumar, P.: A multiple scale state-space model for characterizing subgrid scale variability of near-surface soil moisture, IEEE T. Geosci. Remote, 37, 182-197, 1999.

Lannoy, G. J. M., Reichle, R. H., Houser, P. R., Arsenault, K. R., Verhoest, N. E. C., and Pauwles, V. R. N.: Satellite-scale snow water equivalent assimilation into a high-resolution and surface model, J. Hydrometeorol., 11, 352-369, 2010.

Lee, J.-E, Oliveira, R. S., Dawon, T. E., and Fung, I.: Root functioning modifies seasonal climate, P. Natl. Acad. Sci., 102, 1757617581, 2005.

Levis, S. and Bonan, G. B.: Simulating springtime temperature patterns in the Community Atmosphere Model coupled to Community Land Model using prognostic leaf area, J. Climate, 17, 45314540, 2004.

Li, Q. and Ishidaira, H.: Development of a biosphere hydrological model considering vegetation dynamics and its evaluation at basin scale under climate change, J. Hydrol., 412-413, 3-13, 2011.

Li, H., Huang, M., Wigmosta, M. S., Ke, Y., Coleman, A. M., Leung, F. W., Wang, A., and Ricciuto D. M.: Evaluating runoff simulations from the Community Land Model 4.0 using observations from flux towers and a mountainous watershed, J. Geophys. Res., 116, D24120, doi:10.1029/2011JD016276, 2011.

Liang, X. and Guo, J.: Intercomparison of land-surface parameterization schemes: sensitivity of surface energy and water fluxes to model parameters, J. Hydrol., 279, 182-209, 2003.

Liang, X. and Xie, Z.: A new surface runoff parameterization with subgrid-scale soil heterogeneity for land surface models, Adv Water Resour., 24, 1173-1193, 2001.

Liang, X., Lettenmaier, D. P. Wood, E. F., and Burges, S. J.: A simple hydrologically based model of land surface water and energy fluxes for general circulation models, J. Geophys. Res., 99 14415-14428, 1994.

Liang, X., Wood, E. F., and Lettenmaier, D. P.: Surface soil moisture parameterization of the VIC-2L model: Evaluation and modifications, Global Planet. Change, 13, 195-206, 1996a.

Liang, X., Lettenmaier, D. P., and Wood, E. F.: One-dimensional statistical dynamic representation of subgrid spatial variability of precipitation in the two-layer variable infiltration capacity model, J. Geophys. Res., 101, 21403-21422, 1996b.

Liang, X., Wood, E., Lettenmaier, D., Lohmann, D., Boone, A., Chang, S., Chen, F., Dai, Y., Desborough, C., Dickinson, R., Duan, Q., Ek, M., Gusev, Y., Habets, F., Irannejad, P., Koster, R., 
Mitchell, K., Nasonova, O., Noilhan, J., Schaake, J., Schlosser, A., Shao, Y., Shmakin, A., Verseghy, D., Wang, J., Warrach, K., Wetzel, P., Xue, Y., Yang, Z., and Zeng, Q.: The Project for Intercomparison of Land-surface Parameterization Schemes (PILPS) Phase 2c. Red-Arkansas River basin experiment: 2. Spatial and temporal analysis of energy fluxes, Global Planet. Change, 19, 137-159, 1998.

Liang, X., Xie, Z., and Huang, H.: A new parameterization for surface and groundwater interactions and its impact on water budgets with the variable infiltration capacity (VIC) land surface model, J. Geophys. Res., 108, 8613, doi:10.1029/2002JD003090, 2003.

Liang, X., Guo, J., and Leung, L. R.: Assessment of the effects of spatial resolution on daily water flux simulations, J. Hydrol., 298, 287-310, 2004.

Lloyd, J., Bloomfield, K., Domingues, T. F., and Farquhar, G. C.: Photosynthetically relevant foliar traits correlating better on a mass vs area basis: of ecophysiological relevance or just a case of mathematical imperatives and statistical quicksand?, New Phytol., 199, 311-321, 2013.

Lohman, D., Lettenmaier, D., Liang, X., Wood, E., Boone, A., Chang, S., Chen, F., Dai, Y., Desborough, C., Dickenson, R., Duan, Q., Ek, M., Gusev, Y., Habets, F., Irannejad, P., Koster, R., Mitchell, K., Nasonova, O., Noilhan, J., Schaake, J., Schlosser, A., Shao, Y., Shmakin, A., Verseghy, D., Wang, J., Warrach, K., Wetzel, P., Xue, Y., Yang, Z., and Zeng, Q.: The project for intercomparison of land-surface parameterization schemes (PILPS) Phase 2c. Red-Arkansas River basin experiment: 3. Spatial and temporal analysis of water fluxes, Global Planet. Change, 19, 161-179, 1998a.

Lohmann, D., Raschke, E., Nijssen B, and Lettenmaier, D. P.: Regional scale hydrology: I. Formulation of the VIC-2L model coupled to a routing model, Hydrol. Sci. J., 43, 131-141, 1998b.

Lu, L., Pielke, R. A., Liston, G. E., Parton, W. J., Ojima, D., and Hartman, M.: Implementation of a two-way interactive atmospheric and ecological model and its application to the central United States, J. Climate, 14900-14919, 2001

Luettgen, M. R. and Willsky, A. S.: Multiscale Smoothing Error Models, IEEE T. Automat. Contr., 40, 173-175, 1995.

Luo, X., Liang, X., and McCarthy, H. R.: VIC+ for water-limited conditions: a study of biological and hydrological processes and their interactions in the soil-plant-atmosphere continuum, Water Resour. Res., 49, 7711-7732, doi:10.1002/2012WR012851, 2013

Luo, Y. Q., Randerson, J. T., Abramowitz, G., Bacour, C., Blyth, E., Carvalhais, N., Ciais, P., Dalmonech, D., Fisher, J. B., Fisher, R., Friedlingstein, P., Hibbard, K., Hoffman, F., Huntzinger, D., Jones, C. D., Koven, C., Lawrence, D., Li, D. J., Mahecha, M., Niu, S. L., Norby, R., Piao, S. L., Qi, X., Peylin, P., Prentice, I. C., Riley, W., Reichstein, M., Schwalm, C., Wang, Y. P., Xia, J. Y., Zaehle, S., and Zhou, X. H.: A framework for benchmarking land models, Biogeosciences, 9, 3857-3874, doi:10.5194/bg-93857-2012, 2012.

Maire, V., Martre, P., Kattge, J., Gastal, F., Esser, G., Fontaine, S., and Soussana, J.-F.: The coordination of leaf photosynthesis links $\mathrm{C}$ and $\mathrm{N}$ fluxes in C3 plant species, PLoS One, 7, e38345, doi:10.1371/journal.pone.0038345, 2012.
Manabe, S.: Climate and the ocean circulation: 1, the atmospheric circulation and the hydrology of the Earth's surface, Mon Weather Rev., 97, 739-805, 1969.

Margulis, S. A., McLaughlin, D., Entekhabi, D., and Dunne, S.: Land data assimilation and estimation of soil moisture using measurements from the Southern Great Plains 1997 field experiment, Water Resour. Res., 38, 1299, doi:10.1029/2001WR001114, 2002.

Maxwell, R. M. and Miller, N. L.: Development of a coupled land surface and groundwater model, J. Hydrometeorol., 6, 233-247, 2005.

McGill, B., Enquist, B. J., Weiher, E., and Westoby, M.: Rebuilding community ecology from functional traits, Trends Ecol. Evol., 21, 178-185, 2006.

McLaughlin, D.: An integrated approach to hydrologic data assimilation: interpolation, smoothing, and filtering, Adv. Water Resour., 25, 1275-1286, 2002.

Medlyn, B. E., Duursma, R. A., Eamus, D., Ellsworth, D. S., Prentice, I. C., Barton, C. V. M., Crous, K. Y., De Angelis, P., Freeman, M., and Wingate, L.: Reconciling the optimal and empirical approaches to modelling stomatal conductance, Glob. Change Biol., 17, 2134-2144, 2011.

Medlyn, B. E., Zaehle, S., De Kauwe, M. G., Walker, A. P., Dietze, M. C., Hanson, P., Hickler, T., Jain, A., Luo, Y., Parton, W. Prentice, I. C., Thornton, P., Wang, S., Wang, Y. P., Weng, E., Iversen, C. M., McCarthy, H., Warren, J., Oren, R. and Norby, R.: Using ecosystem experiments to improve vegetation models, Nature Clim. Change, in press, 2015.

Mengelkamp, H.-T., Warrach, K., and Raschke, E.: SEWAB - a parameterization of the Surface Energy and Water Balance for atmospheric and hydrologic models, Adv. Water Resour., 23, 165$175,1999$.

Milly, P. C. D. and Shmakin, A. B.: Global modeling of land water and energy balances. Part I: the land dynamics (LaD) model, J. Hydrometeorol., 3, 283-299, 2002.

Montaldo, N. and Albertson, J. D.: Multi-scale assimilation of surface soil moisture data for robust root zone moisture predictions, Adv. Water Resour., 26, 33-44, 2003.

Montzka, C., Moradkhani, H., Weihermüller, L., Hendricks Franssen, H. J., Canty, M., and Vereecken, H.: Hydraulic parameter estimation by remotely-sensed top soil moisture observations with the particle filter, J. Hydrol., 399, 410-421, 2011.

Moradkhani, H., Sorooshian, S., Gupta, H. V., and Houser, P. R.: Dual state-parameter estimation of hydrological models using ensemble Kalman filter, Adv. Water Resour., 28, 135-147, 2005 a.

Moradkhani, H., Hsu, K. L., Gupta, H., and Sorooshian, S.: Uncertainty assessment of hydrologic model states and parameters: sequential data assimilation using the particle filter, Water Resour. Res., 41, W05012, doi:10.1029/2004WR003604, 2005b.

Mueller, B., Hirschi, M., Jimenez, C., Ciais, P., Dirmeyer, P. A., Dolman, A. J., Fisher, J. B., Jung, M., Ludwig, F., Maignan, F., Miralles, D. G., McCabe, M. F., Reichstein, M., Sheffield, J., Wang, K., Wood, E. F., Zhang, Y., and Seneviratne, S. I.: Benchmark products for land evapotranspiration: LandFluxEVAL multi-data set synthesis, Hydrol. Earth Syst. Sci., 17, 3707-3720, doi:10.5194/hess-17-3707-2013, 2013.

Murray, S. J., Foster, P. N., and Prentice, I. C.: Evaluation of global continental hydrology as simulated by the Land-surface Pro- 
cesses and eXchanges Dynamic Global Vegetation Model, Hydrol. Earth Syst. Sci., 15, 91-105, doi:10.5194/hess-15-91-2011, 2011.

Murray, S. J., Foster, P. N., and Prentice, I. C.: Future global water resources with respect to climate change and water withdrawals as estimated by a dynamic global vegetation model, J. Hydrol., 448, 14-29, 2012a.

Murray, S. J., Watson, M., and Prentice, I. C.: The use of Dynamic Global Vegetation Models for simulating hydrology and the potential integration of satellite observations, Progr. Phys. Geogr., 37, 63-97, 2012b.

Nijssen, B., Schnur, R., and Lettenmaier, D. P.: Global retrospective estimation of soil moisture using the VIC land surface model, 1980-1993, J. Climate, 14, 1790-1808, 2001.

Nijssen, B., Bowling, L. C., Lettenmaier, D. P., Clark, D. B., El Maayar, M., Essery, R., Goers, S., Gusev, Y., Habets, F., van den Hurk, B., Jin, J., Kahan, D., Lohmann, D., Ma, X., Mahanama, S., Mocko, D., Nasonova, O., Niu, G., Samuelsson, P., Shmakin, A. B., Takata, K., Verseghy, D., Viterbo, P., Xia, Y., Xue, Y., and Yang, Z. L.: Simulation of high-latitude hydrological processes in the Torne-Kalix basin: PILPS Phase 2(e): 2. Comparison of model results with observations, Global Planet. Change, 38, 3153, 2003.

Niu, G. Y., Yang, Z. L., Dickinson, R. E., Gulden, L. E., and Su, H.: Development of a simple groundwater model for use in climate models and evaluation with Gravity Recovery and Climate Experiment data, J. Geophys. Res., 112, D07103, doi:10.1029/2006JD007522, 2007.

Noilhan, J. and Planton, S.: A simple parameterization of land surface processes for meteorological models, Mon. Weather Rev., 117, 536-549, 1989.

Palmer, T. N.: Towards the probabilistic Earth-system simulator: a vision for the future of climate and weather prediction., Q. J. Roy. Meteor. Soc., 138, 841-861, doi:10.1002/qj.1923, 2012.

Pan, M. and Wood, E. F.: Data assimilation for estimating the terrestrial water budget using a constrained ensemble Kalman filter, J. Hydrometeorol., 7, 534-547, 2006.

Pan, M., Wood, E. F., Entekhabi, D., and Luo. L.: A multiscale ensemble filtering system for hydrologic data assimilation. Part I: Implementation and synthetic experiment, J. Hydrometeorol., 10, 794-806, 2009.

Parada, L. M. and Liang, X.: Optimal multiscale Kalman filter for assimilation of near-surface soil moisture into land surface models, J. Geophys. Res., 109, D24109, doi:10.1029/2004JD004745, 2004.

Parada, L. M. and Liang, X.: Impacts of spatial resolutions and data quality on soil moisture data assimilation, J. Geophys. Res., 113, D10101, doi:10.1029/2007JD009037, 2008.

Peters-Lidard, C. D., Zion, M. S., and Wood, E. F.: A soilvegetation-atmosphere transfer scheme for modeling spatially variable water and energy balance processes, J. Geophys. Res., 102, 4303-4324, 1997.

Piao, S., Sitch, S., Ciais, P., Friedlingstein, P., Peylin, P., Wang, X., Ahlström, A, Anav, A., Candell, J. G., Cong, N., Huntingford, C., Jung, M., Levis, S., Levy, P. E., Li, J., Lin, X., Lomas, M. R., Lu, M., Luo, Y., Ma, Y., Myneni, R. B., Poulter, B., Sun, Z., Wang, T., Viovy, N., Zaehle, S., and Zeng, N.: Evaluation of terrestrial carbon cycle models for their response to climate variability and to $\mathrm{CO}_{2}$ trends, Glob. Change Biol., 19, 2117-2132, 2013.
Pitman, A. J.: The evolution of, and revolution in, land surface schemes designed for climate models, Int. J. Climatol., 23, 479510, 2003.

Pitman, A. J., Henderson-Sellers, A., and Yang, Z. L.: Sensitivity of regional climates to localized precipitation in global models, Nature, 346, 734-737, 1990.

Pitman, A. J., de Noblet-Ducoudre, N., Cruz, F. T., Davin, E. L., Bonan, G. B., Broukin, V., Claussen, M., Delire, K., Ganzeveld, L., Gayler, V., van den Hurk, B. J. J. M., Lawrence, P. J., van der Molen, M. K., Muller, R., Reick, C. H., Seneviratne, S. I., Strengers, B. J., and Voldaire, A.: Uncertainties in climate responses to past land cover change: First results from the LUCID intercomparison study, Geophys. Res. Lett., 36, L14814, doi:10.1029/2009GL039076, 2009.

Prentice, I. C.: Ecosystem science for a changing world, Grantham Institute for Climate Change Discussion Papers, 4, 1-16, 2013.

Prentice, I. C. and Cowling, S. A.: Dynamic global vegetation models, in Encyclopedia of Biodiversity, 2nd edition, edited by: Levin, S. A., volume 2, Academic Press, 607-689, 2013.

Prentice, I. C., Bondeau, A., Cramer, W., Harrison, S. P., Hickler, T., Lucht, W., Sitch, S., Smith, B., and Sykes, M. T.: Dynamic global vegetation modelling: quantifying terrestrial ecosystem responses to large-scale environmental change, in: Terrestrial Ecosystems in a Changing World, edited by: Canadell, J., Pitelka, L., and Pataki, D., Springer-Verlag, Berlin, 175-192, 2007.

Prentice, I. C., Dong, N., Gleason, S. M., Maire, V., and Wright, I. $\mathrm{J}$.: Balancing the costs of carbon gain and water loss: testing a new quantitative framework for plant functional ecology, Ecol. Lett., 17, 82-91, 2014.

Qin, J., Liang, S. L., Yang, K., Kaihotsu, I., Liu, R. G., and Koike, T.: Simultaneous estimation of both soil moisture and model parameters using particle filtering method through the assimilation of microwave signal, J. Geophys. Res., 114, D15103, doi:10.1029/2008JD011358, 2009.

Quijano, J. C., Kumar, P., Drewry, D. T., Goldstein, A., and Misson, L.: Competitive and mutualistic dependencies in multispecies vegetation dynamics enabled by hydraulic redistribution, Water Resour. Res., 48, W05518, doi:201210.1029/2011WR011416, 2012.

Randerson, J. T., Hoffman, F. M., Thornton, P. E., Mahowald, N. M., Lindsay, K., Lee, Y. -H., Nevison, C. D., Doney, S. C., Bonan, G., Stöckli, R., Covey, C., Ruming, S. W., and Fung, I. Y.: Systematic assessment of terrestrial biogeochemistry in coupled climate-carbon models, Glob. Change Biol., 15, 2462-2484, 2009.

Raupach, M. P., Rayner, P. J., Barrett, D. J., DeFries, R. S. Heimann, M., Ojuma, D. S., Quegan, S., and Schmullius, C. C.: Model-data synthesis in terrestrial carbon observation methods, data requirements and data uncertainty specifications, Glob. Change Biol., 11, 378-394, 2005.

Rayner, P., Scholze, M., Knorr, W., Kaminski, T., Giering, R., and Widmann, H.: Two decades of terrestrial Carbon fluxed from a Carbon Cycle Data Assimilation System (CCDAS), Global Biogeochem. Cy., 19, GB2026, doi:10.1029/2004GB002254, 2005.

Reichle, R. H., McLaughlin, D. B., and Entekhabi, D.: Hydrologic data assimilation with the ensemble Kalman filter, Mon. Weather Rev., 130, 103-130, 2002a. 
Reichle, R. H., Walker, J. P., Koster, R. D., and Houser, P. R.: Extended versus ensemble Kalman filtering for land data assimilation, J. Hydrometeorol., 3, 728-740, 2002b.

Rosnay, P., Polcher, J., Laval, K., and Sabre, M.: Integrated parameterization of irrigation in the land surface model ORCHIDEE. Validation over Indian Peninsula, Geophys. Res. Lett., 30, 1986, doi:10.1029/2003GL018024, 2003.

Rost, S., Gerten, D., Bondeau, A., Lucht, W., Rohwer, J., and Schaphoff, S.: Agricultural green and blue water consumption and its influence on the global water system, Water Resour. Res., 44, WR09405, doi:10.1029/2007WR006331, 2008.

Ringeval, B., Decharme, B., Piao, S. L., Ciais, P., Papa, F., de Noblet-Ducoudré, N., Prigent, C., Friedlingstein, P., Gouttevin, I., Koven, C., and Ducharne, A.: Modelling sub-grid wetland in the ORCHIDEE global land surface model: evaluation against river discharges and remotely sensed data, Geosci. Model Dev., 5, 941-962, doi:10.5194/gmd-5-941-2012, 2012.

Saeki, A. and Okamura, M.: A fluid-erosion-based model of landscape evolution, Forma, 25, 23-26, 2010.

Schaake, J. C., Koren, V. I., Duan, Q.-Y., Mitchell, K., and Chen, F.: Simple water balance model for estimating runoff at different spatial and temporal scales, J. Geophys. Res., 101, 7461-7475, 1996.

Schellnhuber, H. J., Frieler, K., and Kabat, P.: The elephant, the blind, and the intersectoral intercomparison of climate impacts, P. Natl. Acad. Sci., 111, 3225-3227, 2014.

Scheiter, S. and Higgins, S.: Impacts of climate change on the vegetation of Africa: an adaptive dynamic vegetation modelling approach, Glob. Change Biol., 15, 2224-2246, 2009.

Schlosser, C. A., Slater, A. G., Robock, A., Pitman, A. J., Vinnikov, K. Y., Henderson-Sellers, A., Speranskaya, N. A., Mitchell, K., Boone, A., Baden, H., Chen, F., Cox, P., de Rosnay, P., Desborough, C. E., Dickenson, R. E., Dai, Y., Duan, Q., Entin, J., Etchevers, P., Gedney, N., Gusev, Y., Habets, F., Kim, J., Koren, V., Kowalczyk, E., Nasonova, O., Noilhan, J., Schaake, J., Shmakin, A. B., Smirnova, T. G., Verseghy, D., Wetzel, P., Xue, Y., and Yang, Z.: Standalone simulations of a boreal hydrology with land surface schemes used in atmospheric models: PILPS Phase 2(d), Mon. Weather Rev., 128, 301-321, 2000.

Scholze, M., Allen, J. I., Collins, W. J., Cornell, S. E., Huntingford, C., Joshi, M., Lowe, J. A., Smith, R. S., and Wild, O.: Earth system models: a tool to understand changes in the Earth system, in: Understanding the Earth System. Global Change Science for Applications, edited by: Cornell, S. E., Prentice, I. C., House, J. I., and Downy, C. J., Cambridge University Press, Cambridge, 129-159, 2013.

Sellers, P. J., Dickinson, R. E., Randall, D. A., Betts, A. K., Hall, F. G., Berry, J. A., Collatz, G. J., Denning, A. S., Mooney, H. A., Nobre, C. A., Sato, N., Field, C. B., and Henderson-Sellers, A.: Modeling the exchanges of energy, water, and carbon between continents and the atmosphere, Science, 275, 502-509, 1997.

Sellers, P. J., Mintz, Y., Sud, Y. C., and Dalcher, A.: A simple biosphere model $(\mathrm{SiB})$ for use within general circulation models, J. Atmos. Sci., 43, 505-531, 1986.

Sellers, P. J., Randall, D. A., Collatz, C. J., Berry, J. A., Field, C. B., Dazlich, D. A., Zhang, C., Collelo, G., and Bounoua, L.: A revised land-surface parameterization ( $\mathrm{SiB} 2)$ for atmospheric GCMs. Part 1: model formulation, J. Climate, 9, 676-705, 1996.
Shao, Y. and Henderson-Sellers, A.: Validation of soil moisture simulation in land-surface parameterization schemes with HAPEX data, Global Planet. Change, 13, 11-46, 1995.

Shuttleworth, W. J.: Macrohydrology - The new challenge for process hydrology, J. Hydrol., 100, 31-56, 1988.

Siriwardena, L., Finlayson, B. L., and McMahon, T. A.: The impact of land use change on catchment hydrology in large catchments: The Comet River, Central Queensland, Australia, J. Hydrol., 326, 199-214, 2006.

Smith, M. J., Purves, D. W., Vanderwel, M. C., Lyutsarev, V., and Emmott, S.: The climate dependence of the terrestrial carbon cycle, including parameter and structural uncertainties, Biogeosciences, 10, 583-606, doi:10.5194/bg-10-583-2013, 2013.

Sokolov, A. P., Kicklighter, D. W., Melillo, J. M., Felzer, B., Schlosser, C. A., and Cronin, T. W.: Consequences of considering carbon/nitrogen interactions on the feedbacks between climate and the terrestrial carbon cycle, J. Climate, 21, 3776-3796, 2008.

Sun, Y., Gu, L., Dickenson, R. E., Norby, R. J., Pallardy, S. G. and Hoffman, F. M.: Impact of mesophyll diffusion on estimated global land $\mathrm{CO}_{2}$ fertilization, Proc. Natl. Acad. Sci. USA, 111, 15774-15779, 2014.

Tang, G. P. and Bartlein, P. J.: Simulating the climatic effects on vegetation: approaches, issues and challenges, Progr. Phys. Geogr., 32, 543-556, 2008.

Thornton, P. E., Lamarque, J.-F., Rosenbloom, N. A., and Mahowald, N. M.: Influence of carbon-nitrogen cycle coupling on land model response to $\mathrm{CO}_{2}$ fertilisation and climate variability, Global Biogeochem. Cy., 21, GB4018, doi:10.1029/2006GB002868, 2007.

Todd-Brown, K. E. O., Randerson, J. T., Post, W. M., Hoffman, F. M., Tarnocai, C., Schuur, E. A. G., and Allison, S. D.: Causes of variation in soil carbon simulations from CMIP5 Earth system models and comparison with observations, Biogeosciences, 10, 1717-1736, doi:10.5194/bg-10-1717-2013, 2013.

Turcotte, D. L.: Self-organised complexity in geomorphology: observations and models, Geomorphology, 91, 302-310, 2007.

Tuzet, A., Perrier, A., and Leuning, R.: A coupled model of stomatal conductance, photosynthesis and transpiration, Plant Cell Environ., 26, 1097-1116, 2003.

van Bodegom, P. M., Douma, J. C., Witte, J. P. M., Ordoñez, J. C., Bartholomeus, R. P., and Aerts, R.: Going beyond limitations of plant functional types when predicting global ecosystematmosphere fluxes: exploring the merits of traits-based approaches, Glob. Ecol. Biogeogr., 21, 625-636, 2012.

van der Hurk, B., Best, M., Dirmeyer, P., Pitman, A., Polcher, J., and Santanello, J.: Acceleration of land surface model development over a decade of GLASS, B. Am. Meteorol. Soc., 1593-1600, 2011.

Verseghy, D. L., McFarlane, N. A., and Lazare, M.: CLASS - a Canadian Land Surface Scheme for GCMs II: vegetation model and coupled runs, Int. J. Climatol., 13, 347-370, 1993.

Vicca, S., Luyssaert, S., Peñuelas, J., Campiolo, M., Chapin III, F. S., Ciais, P., Heinemeyer, A., Högberg, P., Kutsch, W. L., Law, B. E., Malhi, Y., Papel, D., Piao, S. L., Reichstein, M., Schulze, E. D. and Janssens, I. A.: Fertile forests produce biomass more efficiently, Ecol. Lett, 15, 520-526, 2012. 
Viterbo, P. and Beljaars, C. M.: An improved land surface parameterization scheme in the ECMWF model and its validation, J. Climate, 8, 2716-2746, 1995.

Vrugt, J. A., ter Braak, C. J. F., Diks, C. G. H., and Schoups, G.: Hydrologic data assimilation using particle Markov chain Monte Carlo simulation: Theory, concepts and applications, Adv. Water Resour., 51, 457-478, 2013.

Walker, J. P. and Houser, P. R.: A methodology for initializing soil moisture in a global climate model: Assimilation of near-surface soil moisture observations, J. Geophys. Res., 106, 11761-11774, 2001.

Wang, D. and Wang, G.: Toward a robust canopy hydrology scheme with precipitation subgrid variability, J. Hydrometeorol., 8, 439446, 2007.

Wang, G.: Assessing the potential hydrological impacts of hydraulic redistribution in Amazonia using a numerical modeling approach, Water Resour. Res., 47, W02528, doi:10.1029/2010WR009601, 2011.

Wang, H., Prentice, I. C., and Davis, T. W.: Biophsyical constraints on gross primary production by the terrestrial biosphere, Biogeosciences, 11, 5987-6001, doi:10.5194/bg-11-5987-2014, 2014.

Wang, Y. P., Trudinger, C. M., and Enting, I. G.: A review of applications of model-data fusion to studies of terrestrial carbon fluxes at different scales, Agr. For. Meterol., 149, 1829-1842, 2009.

Wang, Y. P., Law, R. M., and Pak, B.: A global model of carbon, nitrogen and phosphorus cycles for the terrestrial biosphere, Biogeosciences, 7, 2261-2282, doi:10.5194/bg-7-2261-2010, 2010.

Wang, Y. P., Lu, X. T., Wright, I. J., Dai, Y. J., Raynor, P. J., and Reich, P. B.: Correlations among leaf traits provide a significant constraint on the estimate of global gross primary production, Geophys. Res. Lett., 39, L19405, doi:10.1029/2012GL053461, 2012.

Webler, G., Roberti, D. R., Cuadra, S. V., Moreira, V. S., and Costa, M. H.: Evaluation of a dynamic Agroecosystem Model (AgroIBIS) for soybean in Southern Brazil, Earth Interact., 16, 1-15, 2012.

Wen, Z., Liang, X., and Yang, S.: A new multiscale routing framework and its evaluation for land surface modeling applications, Water Resour. Res., W08528, doi:10.1029/2011WR011337, 2012.

Wetzel, P. J. and Boone, A.: A parameterization for landatmosphere-cloud exchange (place) - documentation and testing of a detailed process model of the partly cloudy boundary-layer over heterogeneous land, J. Climate, 8, 1810-1837, 1995.

Winter, T. C.: The concept of hydrologic landscapes, J. Am. Water Resour. Ass., 37, 335-349, 2001.
Wood, E. F., Lettenmaier, D. P., Liang, X., Lohmann, D., Boone, A., Change, S., Chen, F., Dai, Y., Dickinson, R., Duan, Q., Ek, M., Gusev, Y., Habets, F., Irannejad, P., Koster, R., Mitchell, K., Nasonova, O., Noilhan, J., Schaake, J., Schlosser, A., Shao, Y., Shmakin, A., Verseghy, D., Warrach, K., Wetzel, P., Xue, Y., Yang, Z., and Zeng, Q.: The project for intercomparison of land-surface parameterization schemes (PILPS) phase 2(c) RedArkansas River basin experiment: 1. Experiment description and summary intercomparisons, Global Planet. Change, 19, 115135, 1998.

Wright, I. J., Reich, P. B., and Westoby, M.: Least-cost input mixtures of water and nitrogen for photosynthesis, Amer. Nat., 161, 98-111, 2003.

Wright, I. J., Reich, P. B., Westoby, M., Ackerly, D. D., Baruch, Z., Boners, F., Cavender-Bares, J., Chapin, T., Cornelissen, J. H. C., Diemer, M., Flexous, J., Garnier, E., Groom, P. K., Gulias, J., Hikosaka, K., Lamont, B. B., Lee, T., Lee, W., Lusk, C., Midgley, J. J., Navas, M.-L., Niinements, Ü., Oleksyn, J., Osada, N., Poorter, H., Post, P., Prior, L., Pyankov, V. I., Roumet, C., Thomas, S. C., Tjoelker, M. G., Veneklass, E. J., and Villar, R.: The worldwide leaf economics spectrum, Nature, 428, 821-827, 2004.

Xia, J. X., Luo, Y., Wang, Y.-P., and Hararuk, O.: Traceable components of terrestrial carbon storage capacity in biogeochemical models, Glob. Change Biol., 19, 2104-2116, 2013.

Xue, Y., Sellers, P. J., Kinter, J. L., and Shukla, J.: A simplified biosphere model for global climate studies, J. Climate, 4, 345364, 1991.

Yeh, P. J.-F, and Eltahir, E. A. B.: Representation of water table dynamics in a land surface scheme: 1 . Model development, J. Climate, 18, 1861-1880, 2005.

York, J. P., Person, M., Gutowski, W. J., and Winter, T. C.: Putting aquifers into atmospheric simulation models: An example from the Mill Creek Watershed, north-eastern Kansas, Adv. Water Resour., 54, 221-238, 2002.

Zaehle, S., Medlyn, B. E., De Kauwe, M. G., Walker, A. P., Dietze, M. C., Hickler, T., Luo, Y., Wang, Y.-P., El-Masri, B., Thornton, P., Jain, A., Wang, S., Wårlind, D., Weng, E., Parton, W., Iversen, C. M., Gallet-Budynek, A., McCarthy, H., Finzi, A., Hanson, P. J., Prentice, I. C., Oren, R., and Norby, R. J.: Evaluation of 11 terrestrial carbon-nitrogen cycle models against observations from two temperate Free-Air $\mathrm{CO}_{2}$ Enrichment studies, New Phytol., 202, 803-822, 2014.

Zhou, S., Duursma, R., Medlyn, B. E., Kelley, J. W. G., and Prentice, I. C.: How should we model plant responses to drought? An analysis of stomatal and non-stomatal responses to water stress, Agr. For. Meteorol., 182-183, 204-214, 2013. 